\title{
NOTES ON THE FAMILY AMPULLARIIDAE (GASTROPODA: PROSOBRANCHIA) IN THE PHILIPPINES: I. DIGESTIVE, CIRCULATORY, AND EXCRETORY SYSTEMS
}

\author{
ROBERTOC. PAOULAYAN and ELPIDIO A. REMIGIO \\ Institute of Biology, College of Science, \\ University of the Philippines, Diliman, Quezon City, Philippines
}

\begin{abstract}
A total of 232 ampullariid snails collected from 23 sites covering 7 islands in the Philippines were compared conchologically and 200 alcohol-preserved specimens were dissected for anatomical characteristics. Conchological comparison of the shells of the collected snails with that of identified lots from the Senckenberg Natur-museum, Frankfurt, Germany, the British Museum for Natural History, London, England, the Koninklijk Belgisch Instituut voor Natuurwetenschappen, Brussels, Belgium, and the Rijksmuseum voor Natuurwetenschappen, Leiden, Netherlands, revealed the presence of 5 species in the collected samples. These are: $P$. conica, $P$. ampullacea, $P$. mainitensis, $P$. quadrasi, and $P$. vittala. The latter 3 species were previously reported as being indigenous to the Philippines.

Aside from characteristics of the shell, the morphology of the stomach may be useful for species discrimination. $P$. quadrasi and $P$. vittata, however, do not seem to differ anatomically from $P$. conica.
\end{abstract}

\section{INTRODUCTION}

Information on the taxonomy of the Philippine snails belonging to the family Ampullariidae (Pilidae) is very deficient. There is a dearth of critical scientific data available aside from the initial reports on pilids from the Philippines written more than a century ago by Philippi (1851) and Reeve (1856). Although a number of species has been named and described, an accurate account of the number of existing species and a more reliable system of identification have yet to be clearly established. Species differentiation has been based primarily on a very limited set of shell samples with rather polymorphic conchological features.

Examination of type and collected specimens in the following museums: the Senckenberg Natur-Museum (SMN), Frankfurt a.M., Germany; the British Museum of Natural History (BMNH), London, England; the Koninklijk Belgisch Instituut voor Natuurwetenschappen (KBIN), Brussels, Belgium; and the Rijksmuseum voor Natuurwetenschappen (RVN), Leiden, Netherlands, as well as extensive literature search revealed that 9 nominal species of Pila have been recorded from the 


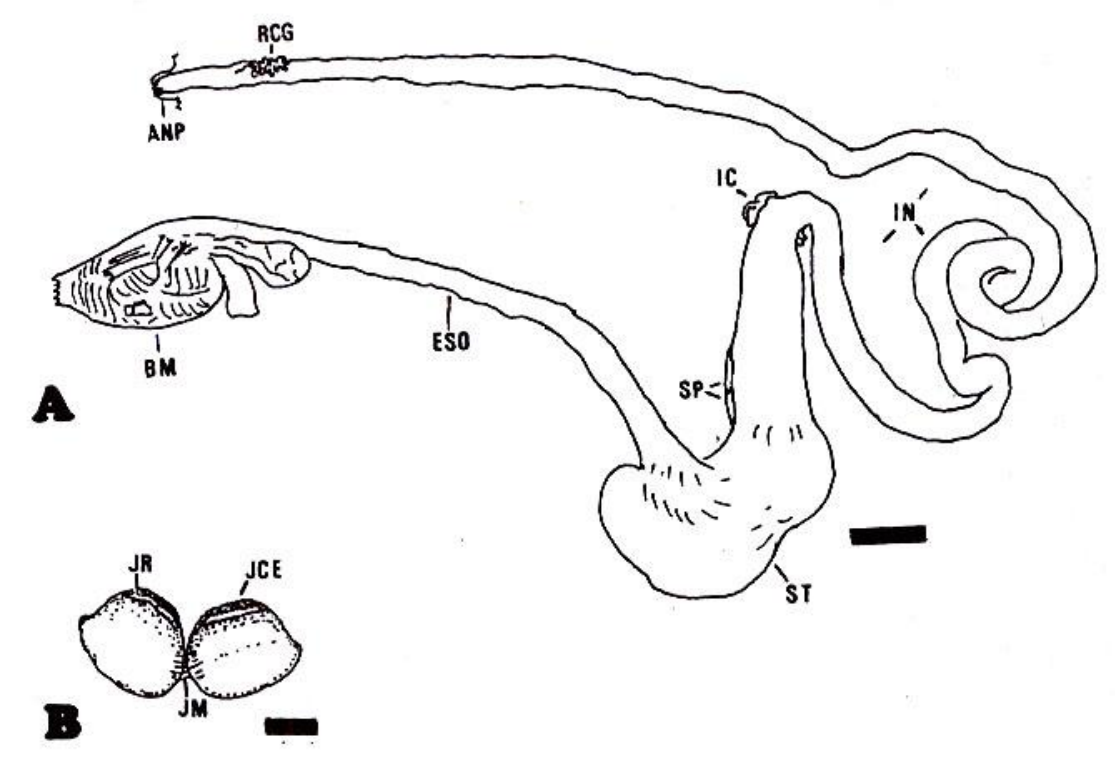

Figure 6. A. The alimentary tract of $P$. conica. Bar $=3 \mathrm{~mm}$. B. Jaws of $P$. conica. Bar $=1 \mathrm{~mm}$.

Abbreviations to figures see Appendix 2.

also roughly the boundary of the buccal mass with the esophagus. At this region, the roof of the buccal cavity is slightly thickened and is furrowed longitudinally. From this region the cavity leads to the esophagus dorsally and into the radular sac ventrally. The junction between the two entrances being an extended, furrowed flap (FF), corresponding to the elliptical pad of $P$. globosa (Prashad 1925).

The chitinous jaws (Fig. 6B) are connected to each other on their dorsal edges by a very thin membrane (JM). Each jaw is roughly oval in outline, with a thickened slightly serrated cutting edge (JCE) which is also the most anterior edge of the jaw. A ridge (JR) is present that serves as the attachment of the jaws to the sphincter muscle. The cutting edge itself is slightly curved inwards. The more posterior portion of each jaw is thinner and bears a slight projection at its ventral edge.

Except for differences in size, which is dependent on the size of the snail, the jaws of the other species examined are similar to that of $P$. conica.

There are two pairs of cartilages, the superior and lateral cartilages. The superior cartilages (Fig. 8D: SC) are small somewhat triangular structures on the lateral sides of the anterior portions of the radula. Medial and posterior to them 
Notes on the family Ampullariidae in the Philippines - R.C. Pagulayan \& E.A. Remigio

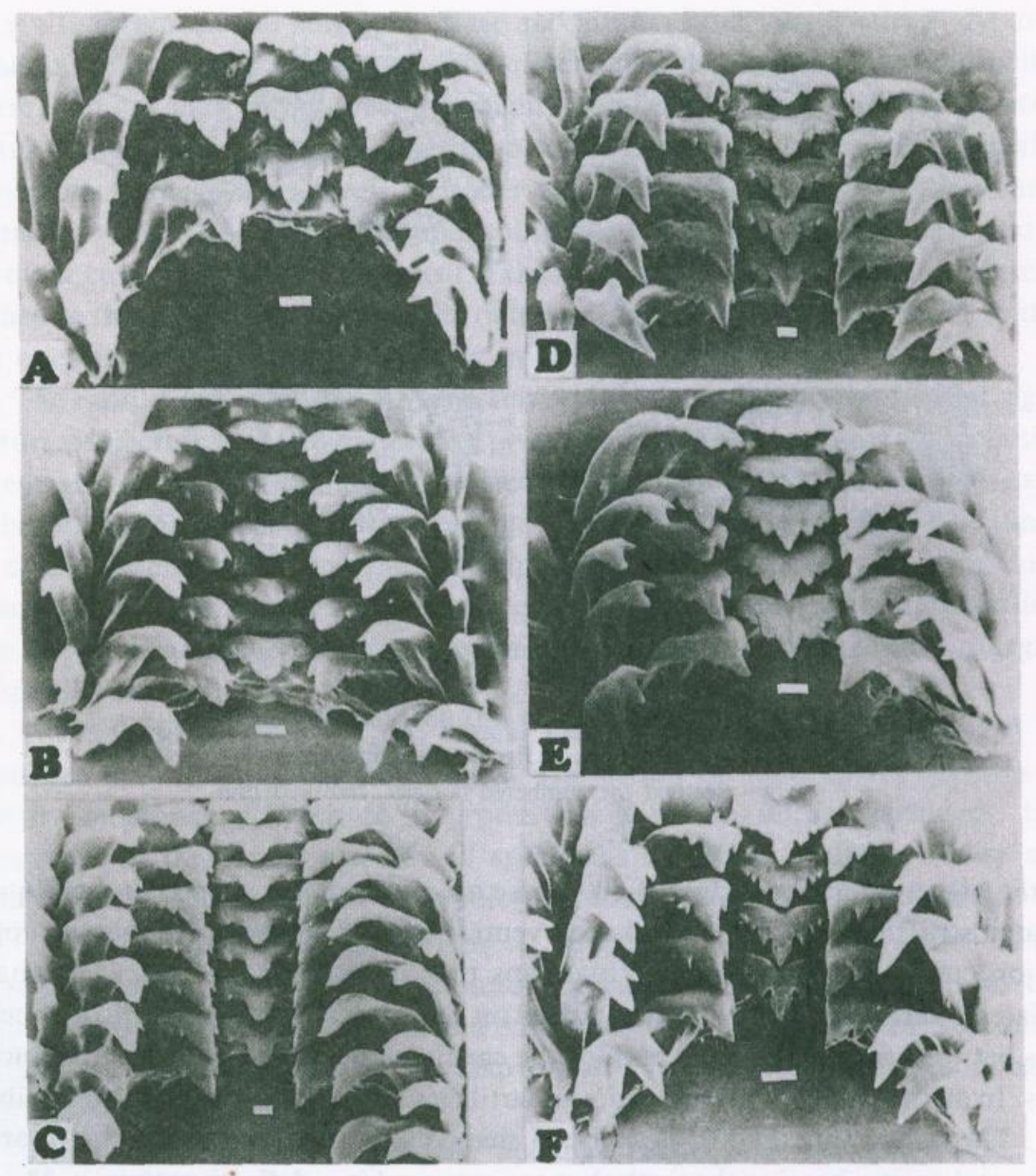

Figure 7. Representative radula of the tentatively identified species.
A. P. conica: Lake Mainit, Surigao del Norte.
B. P. ampullacea: Lake Manguiao, Palawan.
C. P. ampullacea: Magallanes, Sorsogon.
D. P. mainitensis: Oacao, Palo, Leyte.
E. $P$. vittata $(=P$. conica $):$ Sta. Cruz, Marinduque.
F. P. quadrasi $(=$ P. conica): Lamluad Valley, Lake Sebu, So. Cotabato.
Bar $=100 \mu \mathrm{m}$. 

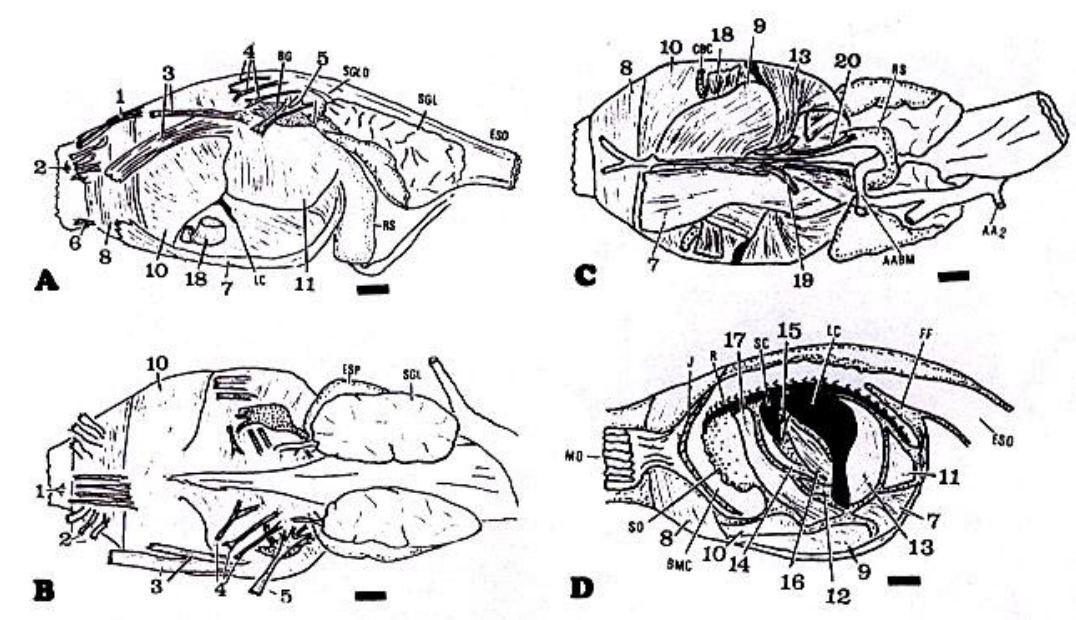

Figure 8. Buccal mass musculature of P. conica.
A. side view
B. dorsal view
C. ventral view
D. longitudinal section
Abbreviations in figures see Appendix 2.
See text for numbered muscles. Bar $=1 \mathrm{~mm}$.

are the bigger lateral cartilages (LC). These are somewhat S-shaped and obliquely situated structures, having a thickened ventral edge. The relatively thinner upper portion curves inward and partly overlaps that of the opposite side. Externally the lateral cartilages can be seen as ridges on the ventro-lateral sides of the buccal mass between the muscles, the bulk of the cartilages being embedded in the buccal mass. In all the specimens examined, the cartilages are of similar shape and number.

The radula (Fig. 8D: R) is a ribbon shaped structure, located on the floor of the buccal cavity, bearing the teeth that are arranged in a definite pattern in $33-41$ similar transverse rows. The radula is taenioglossate (Fig. 7A) - consisting of seven teeth in the transverse row, one central (rhachidian) flanked on each side by one lateral and two marginals. The general radular formula is 2-1-1-1-2. The marginals, laterals, and to a certain extent the rhachidians overlap and obscure from view their structures. During preparation, individual teeth were deflected in order to reveal and clearly observe their fine features. The rhachidian teeth have horizontally elongated body from which 7 cusps project. The anterior margin of the body is grooved. The central cusp is the largest, triangular, spade-like, or dagger-like in form. There are two lateral teeth per row. Each has a base that is elongated obliquely, with prominent ridges on the dorsal surface. The body is basically shouldered and typically bears five cusps: a large mesocone, a small endocone and ectocone, a basal 
cusp at the antero-medial part of the base and hidden from view by the body, and another cusp lateral to the ectocone. The mesocone is the largest cusp, dagger-like in form, and has smoothly curved or straight lateral edges terminating in a pointed structure. There are four marginal teeth to a row. They are smaller than the laterals. Immediately outer to the laterals are inner marginal teeth with narrow bases and longitudinal ridges. An inner marginal tooth has two cusps, a small inner and a large outer cusp. A basal lobe is present at the base projecting posteriorly and firmly attached to the redular membrane. The outer marginal is essentially identical to the inner one but lacks a basal lobe and is smaller.

The radular sac (Fig. 8A: RS) is a short, rather tubular, and somewhat rigid structure projecting ventrally out of the posterior end of the buccal mass from the midventral line. Internally, the more posterior portion of the radula lies in this sac as a broad ribbon whose posterior end reaches the bottom of the sac. The inner wall of the radular sac facing the teeth appears somewhat fleshy and is in close contact with it. This part of the wall also extends to the buccal cavity terminating as the elliptical pad that forms the junction between the entrances to the esophagus and radular sac.

The muscular system of the buccal mass (Fig. 8) is highly organized in accordance with its complex movements. The action of some of the muscles is however sometimes difficult to interpret. As with the buccal cartilages, the musculature of the buccal mass in all specimens examined is similar. They are listed in Table 1 according to the terminology of Prashad (1925) and Demian (1964).

There are two salivary glands (Fig. 8: SGL), one on each side, which lie on the postero-dorsal limit of the buccal mass. A short duct (SOLD) starts near the ventral, anterior edge of each gland and enters the buccal mass muscles. The ducts open into the buccal cavity near the flap forming the junction of the esophagus and the radular sac.

The cream colored esophageal pouches (ESP), one on each side, lie ventrolateral to the salivary glands. By careful dissection, they can be separated from the salivary glands. The pouches on each side has an opening into the buccal cavity near the junction of the buccal cavity and the esophagus. The internal walls of the pouches are simple with few, if any, longitudinal ridges.

The esophagus (Fig. 6A: ESO) is a thin-walled tube arising from the postero-dorsal edge of the buccal mass. It continues posteriorly below the floor of the pallial cavity, arching to the left in a wide bend as it enters the visceral mass, slightly narrowing as it continues to the stomach at the level just below the pericardium.

No difference in the form of the salivary glands, esophageal pouches, and esophagus was noted for the other species examined.

The stomach (Figs. 6A: ST \& 9A) is a somewhat complicated pouch located behind the posterior kidney chamber. It is seen externally as a maroon patch partly 
Table 1. Terminology of the muscular system of the buccal mass according to Prashad (1925) and Demian (1964).

\begin{tabular}{|c|c|c|c|c|}
\hline & Muscle & Origion & Insertion & Remarks \\
\hline & $\begin{array}{l}\text { Median Dorsal } \\
\text { protractors }\end{array}$ & $\begin{array}{l}\text { Dorsal body wall of } \\
\text { the snout region }\end{array}$ & $\begin{array}{l}\text { Dorsal side of the } \\
\text { anterior portion } \\
\text { of the mass }\end{array}$ & $\begin{array}{l}2 \text { pairs of thin } \\
\text { and flat muscles }\end{array}$ \\
\hline 2. & Dorso-Laterals & $\begin{array}{l}\text { Tip of snout on } \\
\text { the lateral side }\end{array}$ & $\begin{array}{l}\text { Anterior region of } \\
\text { the buccal mass on } \\
\text { its dorsolateral side }\end{array}$ & $\begin{array}{l}3-4 \text { pairs of thin } \\
\text { muscles }\end{array}$ \\
\hline 3. & $\begin{array}{l}\text { Posterior dorso- } \\
\text { laterals }\end{array}$ & $\begin{array}{l}\text { Tip of snout on the } \\
\text { lateral side }\end{array}$ & $\begin{array}{l}\text { Dorsolateral side } \\
\text { of the mass in } \\
\text { front of the buccal } \\
\text { ganglia }\end{array}$ & $\begin{array}{l}2 \text { pairs of muscles, } \\
\text { one thicker than } \\
\text { the other }\end{array}$ \\
\hline 4. & $\begin{array}{l}\text { Mediodorsal } \\
\text { protractors }\end{array}$ & $\begin{array}{l}\text { Body wall at the } \\
\text { lateral side }\end{array}$ & $\begin{array}{l}\text { Dorsal side of the } \\
\text { mass on the medial } \\
\text { side of the buccal } \\
\text { ganglia }\end{array}$ & $\begin{array}{l}3-4 \text { pairs of thin } \\
\text { muscles usually } \\
\text { divided at their } \\
\text { ends }\end{array}$ \\
\hline 5. & $\begin{array}{l}\text { Postdorsal } \\
\text { protractors }\end{array}$ & Lateral body wall & $\begin{array}{l}\text { Posterior to the } \\
\text { insertion of the } \\
\text { preceeding muscles }\end{array}$ & \\
\hline 6. & $\begin{array}{l}\text { Median ventral } \\
\text { protractors }\end{array}$ & $\begin{array}{l}\text { Tip of snout on the } \\
\text { ventral wall }\end{array}$ & $\begin{array}{l}\text { Ventral side of the } \\
\text { mass on the } \\
\text { anterior region }\end{array}$ & $\begin{array}{l}1 \text { pair of small and } \\
\text { short muscles }\end{array}$ \\
\hline 7. & Median protractors & $\begin{array}{l}\text { Ventral wall at the } \\
\text { tip of the snout }\end{array}$ & $\begin{array}{l}\text { Ventral side of the } \\
\text { mass near its } \\
\text { posterior end }\end{array}$ & \\
\hline 8. & Buccal sphincter & - & - & $\begin{array}{l}\text { Circular muscle at } \\
\text { the anterior end of } \\
\text { the mass }\end{array}$ \\
\hline 9. & Ventral superficials & $\begin{array}{l}\text { Ventral median line } \\
\text { of the mass }\end{array}$ & $\begin{array}{l}\text { Poster ventral } \\
\text { edges of the } \\
\text { lateral cartilages }\end{array}$ & $\begin{array}{l}1 \text { pair of broad and } \\
\text { thick intrinsic muscle }\end{array}$ \\
\hline 10. & Anterior jugalis & $\begin{array}{l}\text { Dorsal side of the } \\
\text { mass just behind the } \\
\text { buccal sphincter }\end{array}$ & $\begin{array}{l}\text { Postero-ventral } \\
\text { edges of the } \\
\text { lateral cartilages }\end{array}$ & $\begin{array}{l}1 \text { pair of thick } \\
\text { muscles }\end{array}$ \\
\hline 11. & Posterior jugalis & Dorsal side of mass & $\begin{array}{l}\text { Posterior side of } \\
\text { lateral cartilages }\end{array}$ & $\begin{array}{l}\text { Thin broad muscle } \\
\text { sheet at the dorso- } \\
\text { lateral side of the } \\
\text { posterior portion of the } \\
\text { mass; tapering at its } \\
\text { insertion }\end{array}$ \\
\hline 12. & $\begin{array}{l}\text { Transverse muscle } \\
\text { of the lateral } \\
\text { cartilages }\end{array}$ & -. & - & $\begin{array}{l}\text { Broad and flat } \\
\text { muscle connecting } \\
\text { the two lateral } \\
\text { cartilages on their } \\
\text { ventral edges }\end{array}$ \\
\hline
\end{tabular}


Notes on the family Ampullariidae in the Philippines - R.C. Pagulayan \& E.A. Remigio

Table 1. continued

\begin{tabular}{l}
\hline \multicolumn{1}{c}{ Muscle } \\
\hline 13. Transverse muscles \\
connecting the \\
lateral and \\
superior cartilages
\end{tabular}

14. Transvere muscle connecting the lateral cartilage and the subradular membrane of the radula

15. Ventral muscles connecting the lateral and superior cartilages

16. Tensor superior

17. Tensor inferior

18. Median depressors

19. Median retractors

20. Muscles of the radular sac
Posterior edge of the lateral cartilages Insertion

Remarks

A pair of thick muscles each connecting the posterior edge of the lateral cartilage and the superior cartilage of their corresponding side

Subradular membrane 1 pair of muscles of the radula

\begin{abstract}
A pair of thin muscles on each side, connecting the inner edge of the superior cartilage to the upper anterior edge of the lateral cartilage
\end{abstract}

Inner surface of the lateral cartilage on each side

Subradular membrane 1 pair of muscles of each side of the situated medial to radula the lateral cartilage

\title{
Posterior edge of
} the lateral cartilage on each side

Ventral wall of head Jaws region

Subradular membrane 1 pair of muscles of radula more anteriorly placed than the preceeding

A pair of thick muscle accompanying the cerebro-buccal connective on each side

Subradular membrane Ventral wall of of the radula head region

Posterior wall of the buccal mass
Radular sac

Radular sac



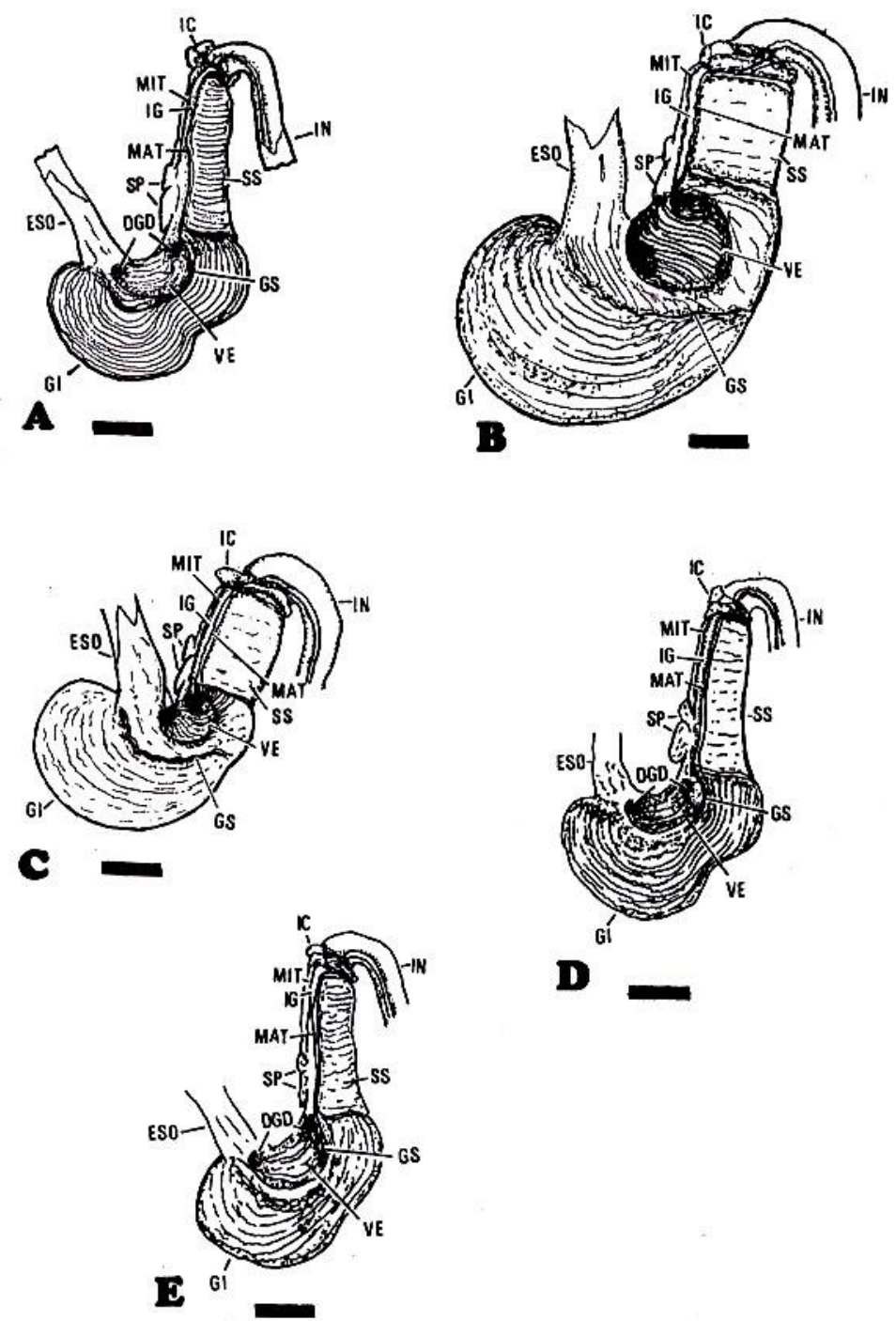

Figure 9. Stomach of representative species (opened along the exposed margin).
A. P. conica: U.P. Lagoon, Quezon City
B. P. ampullacea: Lake Manguiao, Palawan
C. P. mainitensis: Gacao, Palo, Leyte
D. $P$. vittata $(=P$. conica $)$ : Marinduque
E. P. quadrasi ( = /". conica): Lamluad Valley, Lake Sebu, So. Cotabato
Abbreviations in figures see Appendix 2. 
embedded in the digestive gland. Upon exposure by slitting through the patch, the stomach shows a broad J-shaped cavity with a very muscular wall. The innerside is lined by longitudinal ridges. The cavity is divided into two areas, the gizzard (GI) at the anterior portion where the esophagus enters and the narrower, tubular, and relatively straight posterior style sac (SS). The esophagus enters the stomach near the midsection of the smaller (inner) curvature. Posterior to the entrance of the esophagus, at the bend of the curvature, is the semilunar pit (VE), whose wall is elaborated by ridges.. In this pit are openings for the two ducts of the digestive gland (DGO). The margin of the semilunar pit arises as a prominent gastric shield (GS). The gastric shield, together with the wall of the stomach on the other side, prevents food coming from the esophagus, from entering the semilunar pit. The gastric shield at its posterior end continues to the style sac as the major typhlosole (MAT). The wall of the style sac is marked by transverse ridges. Running parallel to the major typhlosole is another ridge, the minor typhlosole (MIT). The major and minor typhlosole border the intestinal groove (IG) between them. Dorsal to the minor typhlosole, at the level of the beginning of the pyloric portion of the stomach, lie two stomach pouches (SP), one smaller than the other. The stomach pouches are somewhat flattened towards the external wall of the stomach and their lumina are separated by a relatively thin vertical septum. No crystalline style in the style sac was found in any of the specimens examined.

The digestive gland (Fig. 4: DG) is a conspicuously greenish mass occupying the upper portions of the spire and partly covering the stomach. Externally, the digestive gland seems to be made up of two distinct lobes, an anterior and posterior lobe, the demarkation made by the position of the stomach as well as that of the two main ducts. Upon dissection, however, the apparently "distinct" lobes are actually fused, having no internal demarkation between them.

The border between the stomach and the intestine is situated just below the pericardium. This junction is a sharp U-shaped loop with a pleated caecum (Fig. 6A \& 9A: 1C). The intestine then runs between the stomach and the posterior chamber of the kidney, following the latter's margin to its posterior end. At this point, the intestine turns back and upwards ventral to the posterior kidney chamber. The intestine then makes several loops and seems to lie inside the cavity of the posterior kidney chamber (Fig. 11B: IN). The intestine then unloops, turning anteriad, running along the opposite margin of the posterior kidney chamber and along the gonoduct on the dorsal side as the rectum. Before the rectum terminates into the rectal papilla, the duct of the rectal gland (Fig. 6A: RCG) enters it on its dorsal side. The gland is branched and is situated at the dorsal side of the rectum on the level of the anterior portion of the gill. The anal papilla (ANP) is a cylindrical 
tube with a fringe opening projecting into the mantle cavity dorsal to the genital opening, as previously described above.

Interspecific variation in the alimentary tract: In $P$. ampullacea, each spadeshaped rhachidian tooth has a central cusp flanked by two pairs of smaller lateral cusps (Figs. 7B \& 7C). Aberrant rhachidian teeth without lateral cusps were also observed in some snails. The lateral teeth have relatively smaller mesocones with smooth lateral edges. There are 35 - 37 rows of teeth in the radula. The rhachidian teeth of $P$. mainitensis (Fig. 7D) is similar to that of $P$. ampullacea but the central cusps are more triangular, resembling an arrow head. The lateral teeth have larger dagger-like mesocone with straight lateral edges. There are 35-36 rows of teeth in the radula. The radular teeth of P. vittata and $\mathrm{P}$. quadrasi (Fig. 7E \& F) are similar to those of $P$. conica.

With respect to the morphology of the stomach, in P. ampullacea (Fig. 9B), the more anterior of the stomach pouches (SP) is not markedly demarkated, giving the stomach an appearance of having only one pouch. It also has a relatively shorter style sac. The stomach of $P$. mainitensis (Fig. 9C) is similar to that of $P$. ampullacea, although, the two stomach pouches are distinct. The stomach of P. vittata and P. quadrasi (Fig. 9D \& 9E) is similar to that of $P$. conica.

No difference in the morphology of the intestine, rectum, and anal papilla was noted between the species examined.

\section{The Circulatory System of $P$. conica}

The pericardial cavity (Fig. 10A: P) is situated on the left side of the body whorl lying between the posterior limit of the pulmonary sac and the kidney on the anterior and the stomach and the digestive gland on the posterior. Its cavity communicates with that of the posterior kidney chamber through the renopericardial duct (Fig. 1 IE: RPO) which runs in the septum that separates the pericardial cavity and posterior kidney chamber. The opening of this duct into the pericardial cavity can best be seen by deflecting the heart to the more anterior side of the pericardium. The opening of the duct is at the anteroventro-lateral wall of the pericardium.

As the other monotocardians, Pila conica has a single auricle and a single ventricle (Figs. 10A \& 10B). The auricle (A) is a thin walled sac capable of great distensions. Internally, fine muscle fibers (AM) in the form of thin bundles runs in various directions. However, most of the muscle fibers run longitudinally from the wall of the entrance to the auricle wall. The ventricle $(\mathrm{V})$ is ovoid in form with a thick muscular wall. The auricle opens into the ventricle through the auriculoventribular opening. This opening is guarded by two valves (AW) attached by thin muscular fibers to the wall of the ventricle. As seen from the inner side, the wall of the ventricle is crisscrossed by large muscle bundles forming a coarse meshwork. 

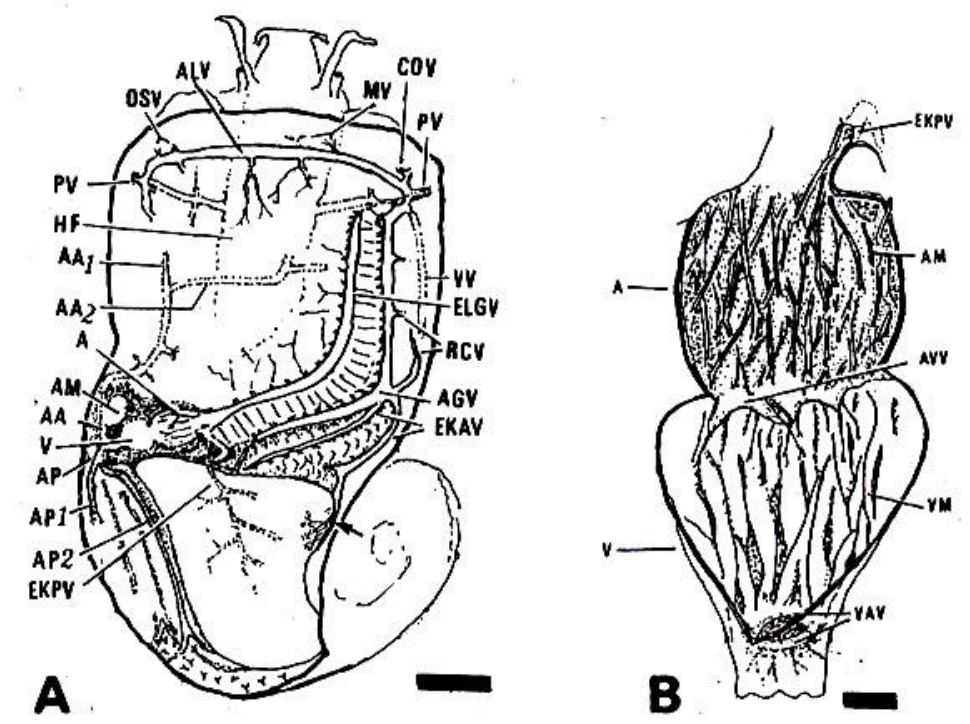

Figure 10. A. General scheme of the circulatory system of $P$. conica. Vessels drawn in solid lines are the more superficial vessels. Vessels drawn in broken lines are the deeper vessels passing through the head foot region and the visceral mass. Bar $=5 \mathrm{~mm}$.

B. Heart (opened to show the internal structures). Bar $=1 \mathrm{~mm}$.

Abbreviations in figures see Appendix 2.

The cavity of the ventricle appears to be reduced, because of these muscular bundles. The ventricle in turn leads to the very short aortic trunk. The entrance of the ventricle to the aortic trunk is also guarded by two smaller valves (VAV).

The morphology of the pericardial cavity and the heart in the other species do not differ from that of $P$. conica.

The ventricle leads to a short aortic trunk at its posterior end. This trunk then divides into the anterior (AA) and posterior aorta (AP). The former turns anteriad and expands into a pouch-like ampulla (AM) occupying the most posterior end of the pericardium. The anterior aorta, shortly after leaving the ampulla, continues in its course anteriad, embedded in the muscular tissue and forming the leftventrolateral wall of the pallium. As the aorta reaches the level of the anterior portion of the esophagus, it splits into two big branches, one branch (AA2) turning right, making an exit from the wall, and emerging into the head sinus (the space surrounding the buccal mass and the anterior portions of the esophagus), the other big branch (AA1) continues its course anteriad eventually breaking into branches that supply blood to the left mantle wall, the osphradium, the left siphon, as well 
Philippines by several workers (Philippi 1851; Reeve 1856; Kobelt 1911; Bequaert and Clench 1939). These species are:

1. Pila conica (Gray 1828)

2. Pila luzonica (Reeve 1856)

3. Pila lubrica (Reeve 1856)

4. Pila vittata (Reeve 1856)

5. Pila ampullacea (Linnaeus 1758)

6. Pila moellendorffi (Kobelt 1911) 1.

Pila mainitensis (Kobelt 1911)

8. Pila quadrasi (Kobelt 1911)

9. Forbesopomus atalanta (Bequaert and Clench 1939)

Up to the present, there are few local studies which have dealt with the other aspects of the snail's biology. Palomino and Jueco (1983) published data on the radula of some freshwater snails including Pila luzonica. They showed the conservative structure of the ampullariid radula but the description lacks important structural detail. Garibay et al. (1987) studied the life history as well as early embryogeny of laboratory-reared pilid snails which were identified as P. luzonica. This study hopes to give additional anatomical data which may be of use towards a better understanding of the ampullariid snails in the Philippines.

\section{MATERIALS AND METHODS}

The study was based on specimens collected in 1986, 1988, 1989 and 1990 from different geographical areas in the Philippines as shown in Figure 1. Brief descriptions of these sites are listed in Appendix 1.

The shells of the snails collected in this study were compared with those of the identified museum lots in order to come up with a tentative identification of the former. Such identification was based on ocular comparison of the shells.

Snail relaxation prior to dissection - snails were first menthol-relaxed before killed and dissected or preserved in $70 \%$ ethyl alcohol. This was done by placing the snails in a small basin with two inches of water. A plastic cover was then placed on top. This plastic cover had a gauze sachet filled with menthol crystals taped on the underside. Caution had been applied to prevent the menthol crystals from falling on the water as the snails are very sensitive and upon contact with menthol will immediately withdraw inside their shells. Relaxation of the snails through "breathing" menthol vapor may be slow but produces the desired result. Normally overnight relaxation was enough. Bigger snails required more time. Relaxed snails were then killed by immersion in $80^{\circ} \mathrm{C}$ water for 30 seconds prior to dissection or preservation. 
as to the surrounding tissue of the left side of the mantle. The branch of the anterior aorta that emerges into the head sinus turns obliquely anteriad and after a short distance crosses the esophagus dorsally as it also gives branches to it. Shortly after crossing to the right side of the esophagus, it subdivides into two branches. The right branch penetrates the right side of the sinus and within this wall, it turns anteriad to supply branches to the right siphon (egestion siphon), the tissue of the right side of the mantle, as well as the copulatory organs. The other branch turns ventrad and supplies blood to the buccal mass, the snout, and the foot region.

The posterior aorta subdivides immediately after leaving the aortic trunk. One branch (Fig. 10A: API) leads to the stomach and, through smaller branches, supplies blood to the various parts of the stomach. The other branch (AP2) can be seen just underneath the mantle epithelium, crossing the junction between the stomach and the intestine, running a course posteriorly between the intestine and the posterior kidney chamber. This artery gives off branches to the intestine, digestive gland, and the gonoduct in this region.

The arterial system of the other species examined is similar to that of $P$. conica. The venous system made up of sinuses consists of the Head-foot sinus, (Fig. 10A: HF). The main trunk of the foot sinus can best be seen by removing the pedal-pleural ganglia complex. Ventrally lies the opening of the foot sinus to the large head sinus. The main trunk of the foot sinus is rather large and situated medially collecting tributaries of smaller sinuses from all parts of the foot. The head sinus is relatively the largest of all sinuses in the snail. It lies above the foot and below the floor of the mantle cavity surrounding the anterior part of the alimentary tract. Some of the blood from this large sinus goes to the tributaries of the pallial vein, through small openings along the left and right walls. These tributaries then unite, on each side, to form the main pallial veins (PV). The right pallial vein joins the afferent gill vein (AGV) and the left pallial vein opens into the afferent lung vein $(\mathrm{ALV})$. The rest of the blood exits from openings on the more posterior portion of the right wall of the head sinus. These openings lead to the sinus through which the sub-intestinal-visceral connective nerve also passes. This sinus (Fig. 1 IB: AKV) continues as the main branch of the afferent kidney vein as it enters the viceral mass.

Afferent kidney vein: (Fig. 11B: AKV). The main branch of this vein turns obliquely inward, becoming larger in diameter. It follows a course along the posterior wall of the columellar muscle, just anterior to the digestive gland where it receives branches from the digestive gland, stomach, and the anterior portions of the intestine, to a level between the junction of the posterior and anterior renal chambers. Here it then divides, one branch to become the afferent vessel of the posterior kidney chamber (AKPV) and the other to become the afferent vessel of the anterior kidney chamber (AKAV). 

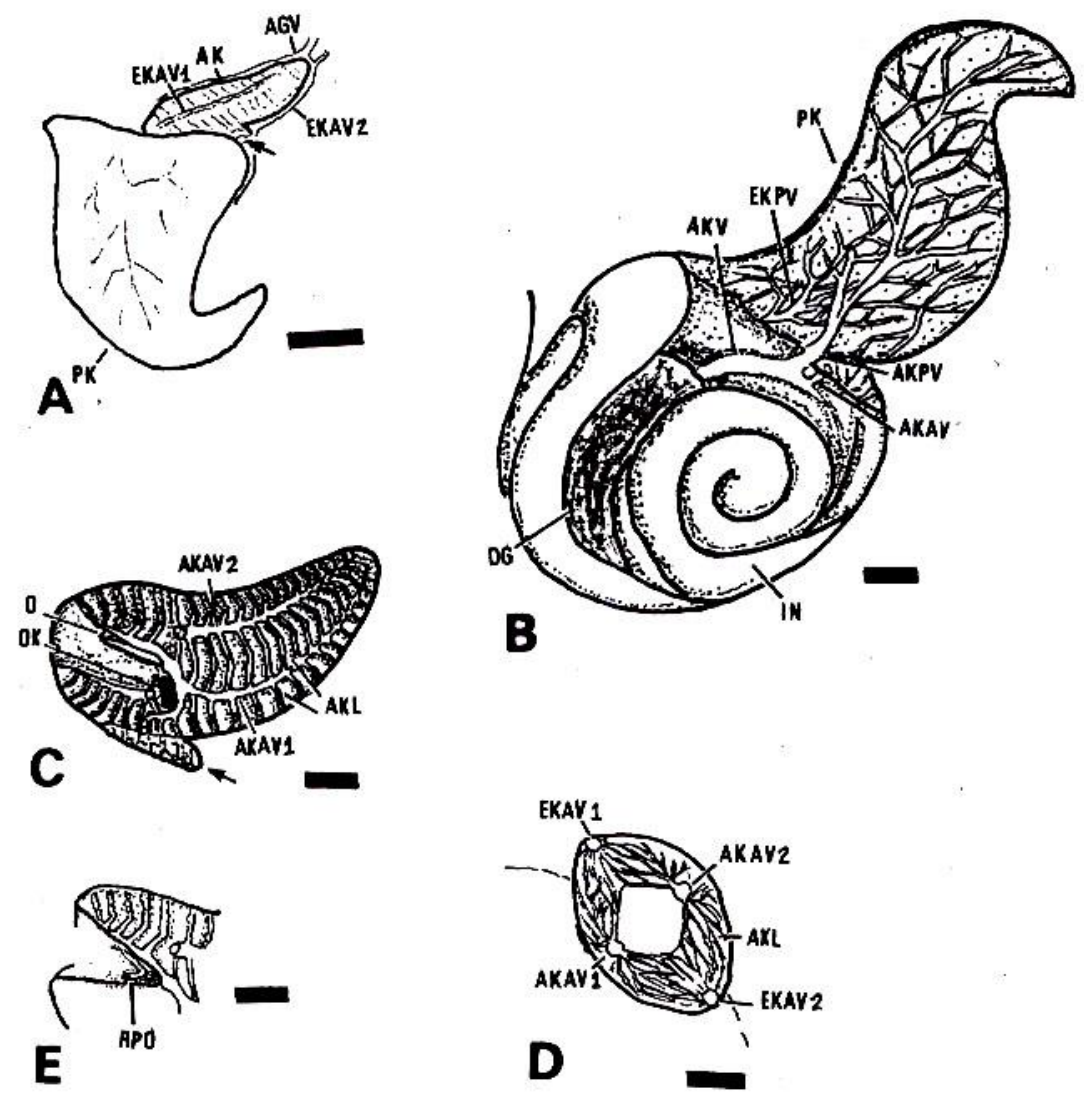

Figure 11. The excretory system of $P$. conica.

A. Dorsal view of the anterior and posterior chambers. Bar $=5 \mathrm{~mm}$.

B. Posterior chamber (opened along its margin). Bar $=1 \mathrm{~mm}$.

C. Anterior chamber (opened to show the internal structure). Arrow points to the extension of its base. Bar $=1 \mathrm{~mm}$.

D. Lamella of the anterior chamber showing position of blood vessels. Bar $=1 \mathrm{~mm}$.

E. Opening between the anterior and posterior chambers cut to show the opening of the reno-pericardial canal. $\mathrm{Bar}=1 \mathrm{~mm}$.

Abbreviations in figures see Appendix 2. 
Branchio-renal complex: This is a system of vessels leading to the gill or in part to the pulmonary sac (Fig. 10A: AGV \& ALV). There are two efferent branches from the anterior kidney chamber (Fig. 10A, 11C \& 1 ID: EKAV). One branch can be seen prominently along its median axis and exiting to the afferent gill vessel. The other branch is located on the posterior edge of the chamber and receives blood from this chamber as well as some blood from the posterior kidney chamber and the intestines. At the anterior tip of the anterior kidney chamber, this branch receives blood coming from the rectum through a short vessel (RCV), then exits to the afferent gill vessel.

The afferent gill vessel (AGV) is a prominent vessel with a relatively large diameter that runs alongside the gill, giving branches to the gill leaflets. At its main trunk it receives two to three short vessels from the rectum on the right side (RCV). At the most anterior end of the afferent gill vessel, it receives blood from the genital and rectal papilla as well as the right pallial and visceral vein. The visceral vein (VV) collects blood from the intestines, and the digestive and genital glands then runs alongside the gonoduct ventrally, collecting blood from it along the way. At its anterior end, it seems to join with the pallial vein shortly before entering the afferent gill vein. The afferent gill vein has also an anterior connection with the afferent pulmonary vessel, running along the margin of the mantle. At the left and right side, the afferent pulmonary vessel (APV) receives branches coming from the osphradium (OSV), the copulatory organ (COV), and branches from the mantle edge (MV).

The vessels leading to the auricle of the heart are as follows: a), the efferent vessel of the posterior kidney chamber (EKPV), whose main trunk and tributaries can be best seen at the inner side of the roof of the chamber. It runs a course through the pericardium entering the extreme right edge of the auricle, its entrance (Fig. 10A \& B: EKPV) being partly obscured by the fine longitudinal muscles of the auricle; $b$ ). the efferent lung-gill vessel (Fig. 10A: ELGV) - This is a relatively big vessel located beneath the skin on the dorsal side running between the edges of the gill and the pulmonary sac. It collects aerated blood from the pulmonary sac and the gill leaflets through a series of small vessels opening on its left and right walls, respectively. It enters the auricle prominently more or less at its tip.

Some differences in the venous system were noted in the other species examined. In P. mainitensis and P. ampullacea, one of the branches of the efferent branch from the anterior kidney chamber (EKAV1) runs along the margin of the anterior kidney, somewhat alongside the afferent gill vessel. As to the vessels entering the auricle, in $P$. mainitensis, there seems to be a short efferent lung vessel that collects blood from the more posterior portion of the sac, aside from the efferent 
lung-gill vessel. This vessel may, however, be simply a part of the efferent lung-gill vessel as it joins the latter before the latter enters the auricle.

The venous system of $P$. vittata and $P$. quadrasi do not differ from that of $P$. conica.

\section{The Excretory System of $P$. conica}

The renal organ or kidney (Fig. 11) consists of two chambers - an anterior and a posterior chamber. The anterior chamber (Fig. $11 \mathrm{~A}$ : AK) could be seen on the upper side of the animal as a reddish brown elongated structure lying to the right of the pericardium after removal of the shell. Its floor projects somewhat into the mantle cavity, and opens into it to the right of the epitaenia. It can be differentiated from the posterior chamber by the lamellated appearance of its inner wall which is seen through the thin mantle epithelium at its dorsal surface. On opening the chamber by making a slit along the roof margin and then deflecting the resulting flap, two longitudinal, whitish, and medially placed structures with triangular lamella arising from their sides could be observed (Fig. 1 IB). These were the main branches of the afferent vessel of the anterior kidney chamber (AKAV1 \& AKAV2) coming from the main trunk of the afferent vessel of the kidneys described above. One branch (AKAV1) is placed on the floor of the chamber while the other (AKAV2) is located at the inner dorsal roof. These vessels divide into smaller branches as they enter the lamellae (Fig. 1 ID). At the periphery of the lamellae, the tiny branches enter the efferent kidney veins of the chamber (EKAV1 \& EKAV2). One of these (EKAV1) is found along the posterior margin of the chamber forming a part of the branchio-renal complex. The other (EKAV2) courses along the dorsal surface of the anterior kidney chamber.

The anterior kidney chamber also forms a branched appendage, projecting from its posterior edge near the junction with the posterior kidney chamber (Fig. $11 \mathrm{~A}$ : arrow). It is also lamellated and forms the dorsal roof of the opening of the anterior kidney chamber into the mantle cavity (Fig. 11B: OK). At this level, but more medially placed on the floor of the chamber, is a longitudinal slit $(\mathrm{O})$. This is the opening through which the posterior kidney chamber communicates with the anterior chamber.

The posterior kidney chamber: (Fig. 11 A: PK). The roof of the posterior kidney chamber prominently lies to left of the rectum as a broad brownish structure with a hooked posterior portion. On making a cut along the margin of the roof and deflecting the flap anteriorly, the spacious cavity of the chamber can be seen (Fig. 1 IB). The soils of the intestine, parts of the genital duct, and portions of the digestive gland can be seen projecting into the cavity. The floor of the chamber consists of a very thin membrane separating the cavity from the organs projecting into it. In 
contrast, the roof of the cavity appears to be thicker and spongy due to the thick plexus formed by the relatively large and branched posterior kidney vessels. There are two main vessels - the afferent (AKAV) and efferent (EKAV) vessels of the posterior chamber, and a minor vessel system (Fig. 10A: arrow) that is found at the right margin of the organ and exits into the branch of the efferent vein of the anterior kidney chamber on that side. The main trunk of the afferent and efferent vein of the posterior chamber is seen prominently placed at the median portion of the chamber's roof.

The posterior kidney chamber is separated from the pericardial cavity by a thin vertical septum. The renopericardial canal connecting the pericardial cavity to the posterior kidney chamber is found in this septum. The canal opens at the tip of a very short papilla very near the longitudinal slit communicating the posterior with the anterior kidney chamber described above (Fig. 1 IE: RPO).

Except for differences in size, which is dependent upon the size of the snail, the morphology of the kidney of the other species examined does not differ from that of $P$. conica.

\section{DISCUSSION}

Distinct difference in mantle or body pigmentation was not observed. Although some snails have shells that have lighter color, yellow or orange without bands, have been observed, such seem to be independent of mantle pigmentation. Snails with lighter colored shells still possess normal black pigmentation of the mantle and the other parts.

All members of the family Ampullariidae are amphibious. Such an adaptation is due to their possession of a ctenidium and a lung sac which are both functioning. This has enabled some members, especially Pila, Lanistes, and Pomacea, to exist in a wide range of habitats (Mozley 1939; Mandahl-Barth 1954; Andrews 1965a). They can, in addition, withstand seasonal drought by aestivating (Meenakshi 1956). Their distribution, however, seems to have a latitudinal limit, being widely distributed only along the tropical and subtropical belt.

In Turbinicola, Asolene, Lanistes, Pomacea, and Marisa (Scott 1943; Kretschmann 1955; Demian 1958; Andrews 1965a), the downgrowth of the mantle which forms the lung sac is relatively extensive. The same observation has been noted in the present study on Pila. In Afropomus balanoides, the lung-sac is formed by a simple circular fold of the roof of the mantle cavity (Berthold 1988). As previously observed in other Pila species, the lung sac of the snails in this study has a wide slitlike aperture, unlike the small aperture reported for Pomacea and Lanistes. The 
development of a small lung sac aperture thus seems to represent convergence towards a small and more efficiently manageable aperture (Andrews 1965a).

Due to its peculiar position, the gill seems to correspond to the osphradium on the left with which, however, it is not homologous (Prashad 1925). As with other monotocardian prosobranchs, the gill of ampullariid snails is actually the left gill which is shoved to the right side by the development of the extensive pulmonary sac (Fretter \& Graham 1962).

One structure that probably plays an important role in the direction of water currents in the mantle cavity, as well as in separating the pulmonary sac from the gill and in providing protection by effectively closing of the ctenidium when the water condition turns foul, is the epitaenia (Andrews 1965a).

The general morphology of the alimentary tract as described is similar in all the species of Pila examined. The characteristics of the radular teeth, especially the differences seen in the number and form of the cusps, have a limited use for species differentiation. This is due to (1) the high probability of the mechanical destruction or modification in the form of the cusps and (2) the observed fusion of cusps in some individuals of the same species.

The basal lobe at the inner marginal tooth was described by Moretto and Nahabedian (1983) for Pomacea canaliculata and by Berthold (1988) for Afropomus balanoides. It was observed in all the snails here examined. Such observation supports Berthold's statement that a basal lobe is present in the inner marginal teeth of all the other pilid genera. The general morphology of the rest of the buccal mass as well as the salivary glands, esophageal pouches, and the anterior portion of the esophagus is also similar to that described for $P$. globosa, M. cornuarietis, P. canaliculata, and A balanoides (Prashad 1925; Scott 1957; Demian 1964; Berthold 1988).

There are two stomach pouches in all the snails examined. The presence of two stomach pouches has also been observed in Marisa cornuarietis (Demian 1964) and Afropomus balanoides (Berthold 1988) and in the Thai Ampullariidae (Keawjam 1987). The stomach pouches in Pila, in this study, were not as big as Keawjam's illustration for the Thai Pilidae. Andrews (1965b) reported only one pouch ("glandular pouch") in Pomacea canaliculata. It is possible that the anterior pouch, as from my observations in $P$. ampullacea, is not so extensive.

Rod-like fecal material in the dissected style sac of some of the snails examined were noted. Compaction of fecal and excretory material seems to occur at the style sac (Andrews 1965b). As previously observed in other genera, there is no crystalline style in the style sac of Pila.

A caecum which seems to be divided into transversely positioned chambers was found in all the snails dissected in this study. It was also described in the other ampullariid genera such as in Afropomus (Berthold 1988) and in Pila, Turbanicola, 
and Pomacea (Andrews 1965b). It may be that the presence of this anterior caecum is a synapomorphy shared by the members of the family Ampullariidae.

Short, semi-compact, pellet like material were noted in the portion of the intestine just after the caecum, giving credence to the suggestion that pellet formation is brought about in the caecum in Pila (Andrews 1965b).

The coiling of the intestine, seen only when the edges of the posterior kidney chamber is cut open, probably needs more attention. In Pila, here examined, and in Afropomus (see Berthold 1988, p. 154,f.Bc), the pattern of coiling is similar, while that of Pomacea (see Andrews 1965b, p.21,f.l) is simpler.

The rest of the posterior portion of the alimentary tract shows no difference from that described by Andrews (1965b) for Pomacea. An anal gland has not been described for Afropomus by Berthold (1988). It may have been overlooked, as was the case for $P$. globosa by Prashad (1925) and for the Thai Ampullariidae by Keawjam (1987). A similar gland appears in some members of the Prosobranchia, including archeogastropods and neogastropods (Hyman 1967). The description of the anal glands of some stenoglossans (Fretter 1946) resembled that of Pila. The anal glands probably play a role in the elimination of excess calcium and iron salts and purines, of which its development in ampullariids may be correlated with their freshwater habits (Andrews 1965b).

As a final note on the digestive gland of Pila, Ranjah (1942) proposed that originally there were two lobes of the digestive gland but the anterior (post-torsional left) lobe is supressed at an early stage in development. Two distinct ducts were observed in all the specimens dissected. Their separated location from each other precludes the presumption that they represent two main branches from a single lobe of the digestive gland. Andrews (1965b) observed that in young Pomacea, there were two distinct lobes, although a single lobe was observed in mature snails. Apparently, the single lobe seen is the result of fusion of the two lobes, such that any border which formerly existed became indistinguishable due to the very close contact between the two lobes. Such a close contact is expected when one considers a very limited space available in the visceral hump for the development of a large structure such as a multifunctional digestive gland.

In all the species examined, the outline of the venous system appeared to be similar, except for that minor difference in the efferent lung-gill vein of P. mainitensis where a short "pulmonary sinus" is located very near the entrance to the auricle. Such a peculiar position gives it an appearance of an independent pulmonary vein. This peculiar sinus, however, opens into the efferent lung-gill vein and not directly into the auricle; therefore it may still be a part of the latter. Prashad (1925) described a distinct pulmonary vein for $P$. globosa, but this was later refuted by Andrews (1965a). Observations on the venous system of the species of Pila examined here are similar to that described by Andrews (1965a). 
Blood from the posterior kidney chamber exits from two points: (1) the larger efferent vessel of the chamber that opens directly into the auricle and (2) two to four small sinuses from the more anterior right margin of the chamber and joining the efferent vein of the anterior chamber at that area. Andrews (1965a) postulates that the larger efferent vein of the posterior chamber is actually the vein from the degenerate nephridial gland. This vein has been enlarged to drain a larger area of the chamber and the actual efferent vein of the chamber is that vessel that joins the second branch of the efferent vessel that drains the anterior chamber.

The basic plan of the arterial system of Pila here examined is similar to that described for other pilids like P. globosa (Prashad 1925), P. canaliculata, T. saxea, L. ovum bangweolicus (Andrews 1965a) and A. balanoides (Berthold 1988). Berthold, however, described a slightly thickened ampulla for Afropomus and added that such a form seems to be plesiomorphic compared to the bigger globular ampulla of the other species mentioned above.

The members of the family Ampullariidae seem to be peculiar in having a kidney made up of two chambers which are morphologically distinct from each other. The general shape as well as position with each other of the anterior and posterior kidney chambers in all the species of Pila here examined is similar to that described by Prashad (1925) and illustrated by Michelson (1961) for P. globosa.

\section{SUMMARY}

1. Species identification of the ampullariid snails in the Philippines was previously based only on characteristics of the shell, hence, an approach was initiated in this study towards basing identification on as many characters as possible.

2. Tentative identification of the collected snails based on conchological comparison with museum specimens were done and five species from the collection were identified. These are: P. conica, P. vittata, P. quadrasi, P. mainitensis, and P. ampullacea.

3. Dissection of the soft anatomical parts revealed few character states in the organ systems here studied which may be useful for species identification. These are: (a) the number of osphradial and gill leaflets, (b) the morphology of the cusps of the rachidian teeth (although caution must be exercised in using this character as the radula is prone to mechanical modification), (c) the morphology of the stomach, and (d) the position of the efferent branch of the anterior kidney chamber (EKAV1). No difference was observed in the other organs here studied.

4. P. vittata and P. quadrasi have been observed to be anatomically indistinct from $P$. conica based on comparison of the digestive, circulatory, respiratory, and excretory systems. 


\section{ACKNOWLEDGEMENTS}

During these studies the authors had the support of several private persons and institutions. Technical assistance or advise was received from Mr. Manny Sapuay of NSRI (photography) and the staff of U.P. N.E.C. (scanning microscope). Prof. Dr. Edmund Gittenberger, Dr. Jackie van Goethem, Dr. Ronald Janssen, and Dr. Peter Mordan for allowing me to examine their collection of Philippine ampullariid snails. Dr. Rita Triebskorn for sending me much needed literature and Dr. Tomas Berthold for sharing his insights on the group of snails studied. Tus and Macy Mamaril and our assistant, Richard Kho for the company and lively discussions during the collection trips. Dr. Gloria L. Enriquez, Dr. Claus Meier-Brook, and Dr. Ruben Umaly for their critical advices and encouragements. The German Academic Exchange Service (DAAD) for supporting the senior author's research scholarship in Germany. The Office of Research Coordination for the research grant that allowed us to collect snails. We also wish to express our gratitude to our countless colleagues in the Institute of Biology and outside the University who have in one way or another contributed to this work.

\section{LITERATURE CITED}

ANDREWS, E.B. 1965a. The functional anatomy of the mantle cavity, kidney, \& blood system of some pilid gastropods (Prosobranchia). J. Zool. 146: 70-94.

1965b. The functional anatomy of the gut of the prosobranch gastropod Pomacea canalicuta and of some other pilids. Proc. Zool. Soc. London 145: 19-36.

BEQUAERT, J.C. \& W.J. CLENCH. 1937. Forbesopomus, a new genus in the family Pilidae (Ampullariidae), from the Philippine Islands. Proc. New Engl. Zool. Club 16: 53-56.

BERTHOLD, T. 1988. Anatomy of Afropomus balanoides (Mollusca: Gastropoda: Ampullariidae) and its implication on phylogeny and ecology. Zoomorphology 108: 149- 159.

DEMIAN, E.S. 1958. On the respiratory system and the mechanisms of respiration in Lanistes bolteni Chemnitz. Ain Shams Sci. Bull. Cairo, 3: 301-316.

1964. The anatomy of the alimentary system ofMarisa comuarietis (L.) Goetoborgs Vetensk. Vitterhets-Samh. Handh. 6 Ser. B 9(2): 1-75.

FERNANDO, W. 1931. The development of the kidney in Ampullaria (Pila) gigas. Proc. Zool. Soc. London 62: 745-750.

FRETTER, V. 1946. The pedal sucker and anal gland of some British Stenoglossa. Proc. Malac. Soc. London 27: 126-130.

FRETTER, V. and A. GRAHAM, 1962. British prosobranch mollusk, their functional anatomy and ecology. Ray Society, London. GARIBAY,J.L., R.C.

PAGUlayan and B. CRUZ 1987. Studies on Pila luzonica Reeve: Hatchability and growth under laboratory conditions. Nat. Appl. Sci. Bull. 39(1): 81-90. 
Notes on the family Ampullariidae in the Philippines - R.C. Pagulayan \& E.A. Remigio

HYMAN, L.H. 1967. The Invertebrates. Volume VI. Mollusca I. McGraw Hill, New York.

KEAWJAM, R. 1987. The apple snails of Thailand: Aspects of comparative anatomy. Malacol. Rev. 20: 69-90.

Kobelt, W. 1911. Die Gattung Ampullaria. In: vol. I, Pt. 29 II (Neue Folge) of Systematisches Conchylien-cabinet von Martini und Chemnitz. Ed. W. Kobelt, von Bauer, und Raspe. Nurnberg: 76-99.

KRETSCHMANN, I. 1955. Untersuchungen ueber Bau und Function der Atmungsorgane bei Ampullarien. Wiss. Z. Humboldt-Univ. Berlin 4: 109-119.

MANDAHL-BARTH, G. 1954. The freshwater mollusks of Uganda and djacent territories. Ann. Mus. Roy. Congo Bel. Tervuren, Sciences Zool. 32: 1-206.

MEENAKSHI, V.R. 1956. Physiology of hibernation of the apple snail Pila virens (Lam.). Curr. Science 25: 21-322.

MICHELSON,E.H. 1961. On the generic limits in the family Pilidae (Prosobranchia: Molluska). Breviora 133: 1-10.

MORETTO, H.J.A. and D.E. NAHABEDIAN, 1983. The radula of Ampullaria canaliculata (Prosobranchia: Mollusca).

Comun. Mus. Arg. Cienc. Nat. Bernardino Rivadaria Inst. Nac. Invest. Cienc. Nat (Arg.) (Hydrobiol.) 2: $107-117$.

MOZLEY, H. 1939. The freshwater molluska of the Tanganyika Territory and Zanzibar Protectorate and their relation to human schistosomiasis. Trans. Roy. Soc. Edinb. 59: 687-744.

PALOMINO, M.L.P. and N.L. JUECO. 1983. Radular pattern in three edible freshwater snails. Kalikasan, Phil. J. Biol. 12: 174-176.

PHILIPPI, R.A. 1851. Die Gattung Ampullaria. In: vol. 1, Pt. 20 of Systematisches Conchylien-cabinet von Martini und Chemnitz. H. Kuster, von Bauer, und Raspe (Eds.) Nurnberg.

PRASHAD, B. 1925. Anatomy of the common Indian apple snail, Pila globosa. Mem. Indian Mus. 8: 91-152.

RANJAH, A.R. 1942. The embryology of the Indian apple snail Pila globosa (Swainson), Mollusca, Gastropoda. Rec. Indian Mus. Calcutta 44: 217-322.

REEVE, L. 1856. Monograph of Ampullaria. Conchologica Iconica 10. London.

SCOTT, M.I.H. 1943. Sobre la organizacion de Ampullaria (Asolene) megastoma Sowerby. Not. Mlis. la Plata 8, Zool. no. 70: 269-280.

1957. Estudio morfologica y taxonomica de los Ampullaridos de la Republica Argentina. Rev. Mus. Argent. Cienc. Nat. (Zool.) 3: 233-333. 
Both menthol-relaxed, alcohol preserved snails and menthol-relaxed, freshly killed snails were used for anatomical studies. The effect of alcohol fixation, particularly on the size of the organs and tensus were noted accordingly.

Dissection of the soft parts - approximately 200 snails were dissected and anatomically examined. The following steps were done in the removal of the soft parts from the shell without crushing the shell. To remove the operculum, a blunt edged, spatula-like probe was inserted in the space between the operculum and its attachment on the dorsal side of the foot. While holding the snail's body steady, the operculum was loosened by pressing at the attachment area with the probe. For the rest of the soft body, the probe had been inserted in the space between the columellar muscle and the shell. By exerting a little pressure, without puncturing the tissue, the muscle was pried loose from its attachment. A pair of forceps was used to grasp the snail's foot and to pull the body out while rotating it, following the coiling of the shell.

Dissection was done under a Wild Zoom Stereomicroscope M7. Exposure of the mantle cavity was accomplished by a cut made beginning at the right mantle edge, dorsal to the exhalant siphon, between the gill and the rectum up to the level of the anterior chamber of the kidney. In exposing the anterior portions of the digestive tract, a longitudinal slit was made starting from the dorsal tip of the snout and continued posteriorly to the area of exit of the esophagus to the visceral mass. After these two major incisions, most of the organs could be seen through the thin mantle and could be reached without much difficulty. They could, therefore, be exposed in situ. Camera lucida drawings were done with a wild drawing tube.

Radulae were obtained by extracting buccal masses from the snails and immersing them in $10 \%$ sodium hydroxide for 24 hours. The radulae were further cleaned by sonication while immersed in $70 \%$ ethanol and subsequently processed for microscopic examination. Some of the radulae were immersed in $10^{\circ} 7$ o sodium hypochlorite to dissolve the radular membrane and facilitate the observation of the lateral lobes of the inner marginal teeth. The rest were eventually air-dried, mounted in specimen blocks, sputter coated with gold using a JEOL Fine Coat Ion Sputter JFC-1100, and examined under a JEOL JSM-35C S.E.M at the National Engineering Center, in U.P. Diliman.

Voucher specimens are presently lodged at the Invertebrate Museum, Institute of Biology, U.P. Diliman, Q.C. and at the Mollusc Division, National Museum, Manila. 
Appendix 1

\begin{tabular}{|c|c|c|}
\hline $\begin{array}{l}\text { ef. PT. } \\
\text { Fig. } 1\end{array}$ & Collection locality & Remarks \\
\hline A & $\begin{array}{l}\text { Ilocos Norte } \\
\text { Prov., Paoay Town, } \\
\text { Paoay Lake }\end{array}$ & $\begin{array}{l}\text { snails collected at edge of lake near the Bureau of Fisheries } \\
\text { station; sandy-muddy substrate; bank vegetation lush, includes } \\
\text { Hydrilla verticillata and Ipomoea aquatica; } 4 \text { snails collected, } 2 \\
\text { males \& } 2 \text { females; Santos, E. collector }\end{array}$ \\
\hline B & $\begin{array}{l}\text { Cagayan Province, } \\
\text { Tuguegarao Town, } \\
\text { Bgy. Cataggaman }\end{array}$ & $\begin{array}{l}\text { snails collected in flooded parts of a ricefield along Barangay } \\
\text { sideroad approximately } 1 \text { kilometer from Pinacanauan River; } \\
\text { muddy substrate; plenty of Ipomoea aquatica and Eichhornia } \\
\text { crassipes; } 21 \text { snails collected, } 9 \text { males, } 12 \text { females; Pagulayan, } \\
\text { R. collector }\end{array}$ \\
\hline C & $\begin{array}{l}\text { Isabela Province, } \\
\text { San Isidro Town }\end{array}$ & $\begin{array}{l}\text { snails collected along banks of an irrigation ditch along main } \\
\text { road to town; muddy substrate; few Ipomoea aquatica; } 12 \\
\text { snails collected, } 7 \text { males, } 4 \text { females; Remigio, E.A. collector }\end{array}$ \\
\hline $\mathrm{D}$ & $\begin{array}{l}\text { Pangasinan Prov., } \\
\text { Carmen Town }\end{array}$ & $\begin{array}{l}\text { snails collected from a shallow irrigation ditch and adjoining } \\
\text { flooded ricefield along the National Highway leading to the } \\
\text { town; plenty of Ipomoea aquatica on: flooded ricefield; } 28 \\
\text { snails collected, } 15 \text { males, } 13 \text { fernales; Pagulayan, R. collector }\end{array}$ \\
\hline E & $\begin{array}{l}\text { Greater Manila } \\
\text { Area, Quezon City, } \\
\text { U.P. Lagoon }\end{array}$ & $\begin{array}{l}\text { snails collected along banks of the lagoon; vegetation lush, } \\
\text { including Eichhornia crassipes, Nelumbo nucifera, Hydrilla } \\
\text { verticillata; } 8 \text { snails collected, } 4 \text { males, } 4 \text { females; Pagulayan, } \\
\text { R. collector }\end{array}$ \\
\hline $\mathrm{F}$ & $\begin{array}{l}\text { Rizal Province, } \\
\text { Tanay Town, Bgy. } \\
\text { Cuyambay, Sitios } \\
\text { Putat \& } \\
\text { Dagat-dagatan }\end{array}$ & $\begin{array}{l}\text { first site on flooded part of ricefield where people catch } \\
\text { mudfish, second site on man-made pond beside stream, snails } \\
\text { collected along edges; both sites with muddy substrate; } 23 \text { snails } \\
\text { collected, } 10 \text { males, } 12 \text { females, } 1 \text { juvenile; Remigio, E.A. \& } \\
\text { Kho, R. collectors }\end{array}$ \\
\hline G & $\begin{array}{l}\text { Sorsogon Prov., } \\
\text { Magallanes Town, } \\
\text { Bgy. Siuton }\end{array}$ & $\begin{array}{l}\text { snails collected after several days of heavy rain from a flooded } \\
\text { ricefield; muddy substrate; } 6 \text { snails collected, } 3 \text { males, } 2 \\
\text { females, } 1 \text { juvenile; Remigio, E.A. collector }\end{array}$ \\
\hline $\mathbf{H}$ & $\begin{array}{l}\text { Oriental Mindoro } \\
\text { Prov., Pinamalayan } \\
\text { Town, Bgy. } \\
\text { Panggulayan }\end{array}$ & $\begin{array}{l}\text { snails collected from two ponds } 50 \text { meter apart and from a } \\
\text { stream nearby; snails along banks or attached to water } \\
\text { hyacinth; muddy substrate; abundant water vegetation; } 5 \text { snails } \\
\text { collected, } 1 \text { male, } 1 \text { female, } 3 \text { juveniles; Remigio, E. \& Kho, } \\
\text { R. collectors }\end{array}$ \\
\hline \multirow[t]{4}{*}{ I } & $\begin{array}{l}\text { Marinduque Province } \\
\text { 1. Boac Town, Bgy. } \\
\text { Buliasnin }\end{array}$ & $\begin{array}{l}\text { snails collected from irrigation canal adjoining a rice field; } \\
\text { substrate of very soft clayish mud; } 8 \text { snails collected, } 4 \text { males, } \\
2 \text { females, } 2 \text { juveniles; Remigio, E. \& Kho, R., collectors }\end{array}$ \\
\hline & $\begin{array}{l}\text { 2. Santa Cruz } \\
\text { Town, Bgy. Aturan }\end{array}$ & $\begin{array}{l}\text { snails collected from a flooded ricefield; muddy substrate; } \\
4 \text { snails collected, } 2 \text { males, } 2 \text { females; Remigio \& Kho, } \\
\text { collectors }\end{array}$ \\
\hline & $\begin{array}{l}\text { 3. Santa Cruz } \\
\text { Town, Bgy. Baliis }\end{array}$ & $\begin{array}{l}\text { snails collected from flooded ricefield; muddy substrate; } \\
4 \text { snails collected, } 1 \text { male, } 3 \text { females; Remigio \& Kho, collectors }\end{array}$ \\
\hline & $\begin{array}{l}\text { 4. Santa Cruz } \\
\text { Town, Bgy. Malabon }\end{array}$ & $\begin{array}{l}\text { snails collected from flooded ricefield; muddy substrate; } \\
4 \text { snails collected, } 1 \text { male, } 3 \text { females; Remigio \& Kho, collectors }\end{array}$ \\
\hline
\end{tabular}


Notes on the family Ampullariidae in the Philippines - R.C. Pagulayan \& E.A. Remigio

Appendix 1. (Continued)

\begin{tabular}{|c|c|c|}
\hline $\begin{array}{l}\text { Ref. PT. } \\
\text { in Fig. } 1\end{array}$ & Collection locality & Remarks \\
\hline & $\begin{array}{l}\text { S. Sta. Cruz Town, } \\
\text { Bgy. Lapu-lapu }\end{array}$ & $\begin{array}{l}\text { snails collected along the bank of a deep pond with lush water } \\
\text { vegetation; pond shaded by trees; } 22 \text { snails collected, } 12 \text { males, } \\
10 \text { females; Remigio \& Kho, collectors }\end{array}$ \\
\hline $\mathbf{J}$ & $\begin{array}{l}\text { Iloilo Province, } \\
\text { Alimodian Town, } \\
\text { Bgy. Cagay, Sitio } \\
\text { Ugis }\end{array}$ & $\begin{array}{l}\text { snails collected from a muddy pool adjacent to rice paddies; } \\
\text { pool with abundant Ipomoea aquatica; } 22 \text { snails collected, } \\
12 \text { male, } 7 \text { females, } 3 \text { juveniles; Remigio, E., collector }\end{array}$ \\
\hline \multirow[t]{3}{*}{$\mathrm{K}$} & $\begin{array}{l}\text { Leyte Province, } \\
\text { Palo Town }\end{array}$ & \\
\hline & 1. Bgy. Gacao & $\begin{array}{l}\text { snails collected from a moderately fast-flowing outlet stream } \\
\text { running through a culvert; snails found in stream edge or } \\
\text { attached to vegetation and litter; water vegetation lush, } \\
\text { Ipomoea aquatica common; muddy-rocky substrate; } 17 \text { snails } \\
\text { collected, } 6 \text { males, } 7 \text { females, } 3 \text { juveniles, } 1 \text { empty shell; } \\
\text { Remigio \& Kho, collectors }\end{array}$ \\
\hline & 2. Bgy. Hubang & $\begin{array}{l}\text { snails collected from an outlet stream running through an } \\
\text { irrigation culvert; slow to stagnant water; rocky-muddy } \\
\text { substrate; thirteen snails, } 5 \text { males, } 7 \text { females, } 3 \text { juveniles; } \\
\text { Remigio \& Kho, collectors }\end{array}$ \\
\hline $\mathrm{L}$ & $\begin{array}{l}\text { Surigao del Norte } \\
\text { Province, Mainit } \\
\text { Town, Lake Mainit }\end{array}$ & $\begin{array}{l}\text { snails collected from an inlet stream leading to the lake; muddy } \\
\text { bottom; abundant water vegetation; } 3 \text { snails collected, all } \\
\text { males; Remigio, E. collector }\end{array}$ \\
\hline \multirow[t]{5}{*}{ M } & $\begin{array}{l}\text { South Cotobato } \\
\text { Province, Lake } \\
\text { Sebu Town }\end{array}$ & \\
\hline & 1. Lake Sebu & $\begin{array}{l}\text { snails collected along bank of lake; sandy-muddy to sandy } \\
\text { substrate; vegetation lush; } 5 \text { snails collected, } 4 \text { males, } \\
1 \text { juvenile; Remigio, E. collector }\end{array}$ \\
\hline & 2. Lamluad Valley & $\begin{array}{l}\text { snails collected from flooded ricefield; muddy substrate; } 13 \\
\text { snails collected, } 3 \text { males, } 9 \text { females, } 1 \text { juvenile; Remigio, E, } \\
\text { collector }\end{array}$ \\
\hline & $\begin{array}{l}\text { So. Cotobato Prov., } \\
\text { Marbel Town, } \\
\text { Bgy. Sta. Cruz }\end{array}$ & $\begin{array}{l}\text { snails collected along the concrete wall of a drainage outlet of a } \\
\text { fishpond-converted swimming pool; } 4 \text { snails collected, all } \\
\text { juvenile; Remigio, E. collector }\end{array}$ \\
\hline & $\begin{array}{l}\text { So. Cotobato Prov. } \\
\text { Koronadal Town, } \\
\text { Barrio } 6\end{array}$ & $\begin{array}{l}\text { snails collected from a muddy ricefield; } 4 \text { snails collected, } \\
1 \text { male, } 1 \text { female, } 2 \text { juveniles; de los Reyes collector }\end{array}$ \\
\hline $\mathrm{N}$ & $\begin{array}{l}\text { Palawan Province, } \\
\text { Lake Manguiao }\end{array}$ & $\begin{array}{l}\text { snails collected from lake edge; vegetation includes floating-leaves } \\
\text { macrophyte Nymphaea nouchali in patches, submerged } \\
\text { macrophytes in mixed stands include Ceratophyllum demersum } \\
\text { and Utricularia aurea; } 1 \text { male snail collected + } 2 \text { empty shells; } \\
\text { Davies, J. collector }\end{array}$ \\
\hline
\end{tabular}


BIOTROPIA No. 6, 1992/1993

Appendix 2.

LIST OF ABBREVIATIONS

\begin{tabular}{|c|c|c|c|}
\hline$\overline{\mathrm{A}}$ & $=$ auricle of the heart & $\overline{\mathrm{J}}$ & $=$ jaws \\
\hline AA & $=$ anterior aorta & JCE & $=$ cutting edge of jaw \\
\hline AABM & $\begin{aligned}= & \text { branch of the anterior aorta to the buccal } \\
& \text { mass }\end{aligned}$ & $\mathrm{JM}$ & $\begin{aligned}= & \text { membrane connecting the two } \\
& \text { jaws }\end{aligned}$ \\
\hline AGV & $=$ afferent gill/ctenidial vessel & JR & $=$ ridge of jaw \\
\hline AK & $=$ anterior kidney chamber & LP & $=$ labial pulps \\
\hline AKAV & $=$ afferent kidney vein to the anterior chamber & LS & $=$ lung/pulmonary sac \\
\hline & $=$ lamella of the anterior kidney chamber & LSO & $=$ opening of the lung sac into \\
\hline \multirow{2}{*}{ AKPV } & $=$ afferent kidney vein to the posterior & & the mantle cavity \\
\hline & chamber & MAT & $=$ major typhlosole \\
\hline $\mathrm{AKV}$ & $=$ main vessel of the afferent kidney vein & MIT & $=$ minor typhlosole \\
\hline ALV & $=$ afferent lung vein & ME & $=$ mantle edge \\
\hline $\mathrm{AM}$ & $=$ auricular muscles & MO & $=$ mouth \\
\hline AMP & $=$ ampulla of the anterior aorta & MV & $=$ mantle veins \\
\hline ANP & $=$ anal $/$ rectal papilla & $\mathrm{O}$ & $=$ slitlike opening between the \\
\hline AP & $=$ posterior aorta & & anterior and posterior kidney \\
\hline AW & $=$ auriculo-ventricular valves & & chambers \\
\hline $\mathrm{BM}$ & $=$ buccal mass & $\mathrm{OK}$ & $=$ opening of the kidney \\
\hline BMC & $=$ cavity of the buccal mass & & chamber into the mantle \\
\hline $\mathrm{C}$ & $=$ columellar muscle & & cavity \\
\hline $\mathrm{CO}$ & $=$ copulatory organ & OPL & $=$ operculiferous lobe on dorsal \\
\hline $\mathrm{COV}$ & $=$ vessels from the copulatory organ & & side of the foot \\
\hline DO & $=$ digestive gland & OS & $=$ osphradium \\
\hline DGD & $=$ duct of the digestive gland & OSV & $=$ osphradial vein \\
\hline E & $=$ eyes & $\mathrm{OV}$ & $=$ ovary \\
\hline \multirow[t]{2}{*}{ EKAV } & $=$ efferent kidney vein from the anterior & $\mathrm{P}$ & $=$ pericardium \\
\hline & chamber & PK & $=$ posterior kidney chamber \\
\hline \multirow[t]{2}{*}{ EKPV } & $=$ efferent kidney vein from the posterior & PV & $=$ pallial vein \\
\hline & chamber & $\mathrm{R}$ & $=$ radulla \\
\hline ELGV & $=$ efferent lung-gill vein & RCG & $=\mathrm{rectal} / \mathrm{anal}$ gland \\
\hline EP & $=$ epitaenia/mantle fold & $\mathrm{RCV}$ & $=$ rectal vein \\
\hline ES & $=$ egestion/exhalant siphon & RPO & $=$ renopericardial opening \\
\hline ESO & $=$ esophagus & RS & $=$ radular sac \\
\hline \multirow[t]{2}{*}{ ESP } & $=$ esophageal pouches & $\mathrm{SC}$ & $\begin{array}{l}=\text { superior cartilage of the } \\
\text { buccal mass }\end{array}$ \\
\hline & & SGL & $=$ salivary gland \\
\hline $\mathrm{F}$ & $=$ foot & SGLD & $=$ salivary gland duct \\
\hline G & $=$ gill $/$ ctenidium & SO & $=$ subradular organ \\
\hline GI & $=$ gizzard & SP & $=$ stomach pouches \\
\hline GP & $=$ genital papilla & SS & $=$ style sac of the stomach \\
\hline GS & $=$ gastric shield & ST & $=$ stomach \\
\hline $\mathrm{HF}$ & $=$ head-foot sinus & $\mathrm{T}$ & $=$ testis \\
\hline HM & $=$ muscles of the internal wall of the heart & TE & $=$ tentacle \\
\hline $1 \mathrm{C}$ & $=$ intestinal caecum & $\mathrm{V}$ & $=$ ventricle \\
\hline IG & $=$ intestinal groove & VA & $=$ ventriculo-aortic valve \\
\hline IN & $=$ intestine & VE & $=$ vestibule \\
\hline \multirow[t]{2}{*}{ IS } & $=$ ingestion/inhalant siphon & VM & $=$ ventricular muscles \\
\hline & & VV & $=$ visceral vein \\
\hline
\end{tabular}




\section{RESULTS}

Species found in the collection sites are map-pinpointed in Figure 1. Representative photographs of the shells of the snails examined are presented in Figures $2 \& 3$.

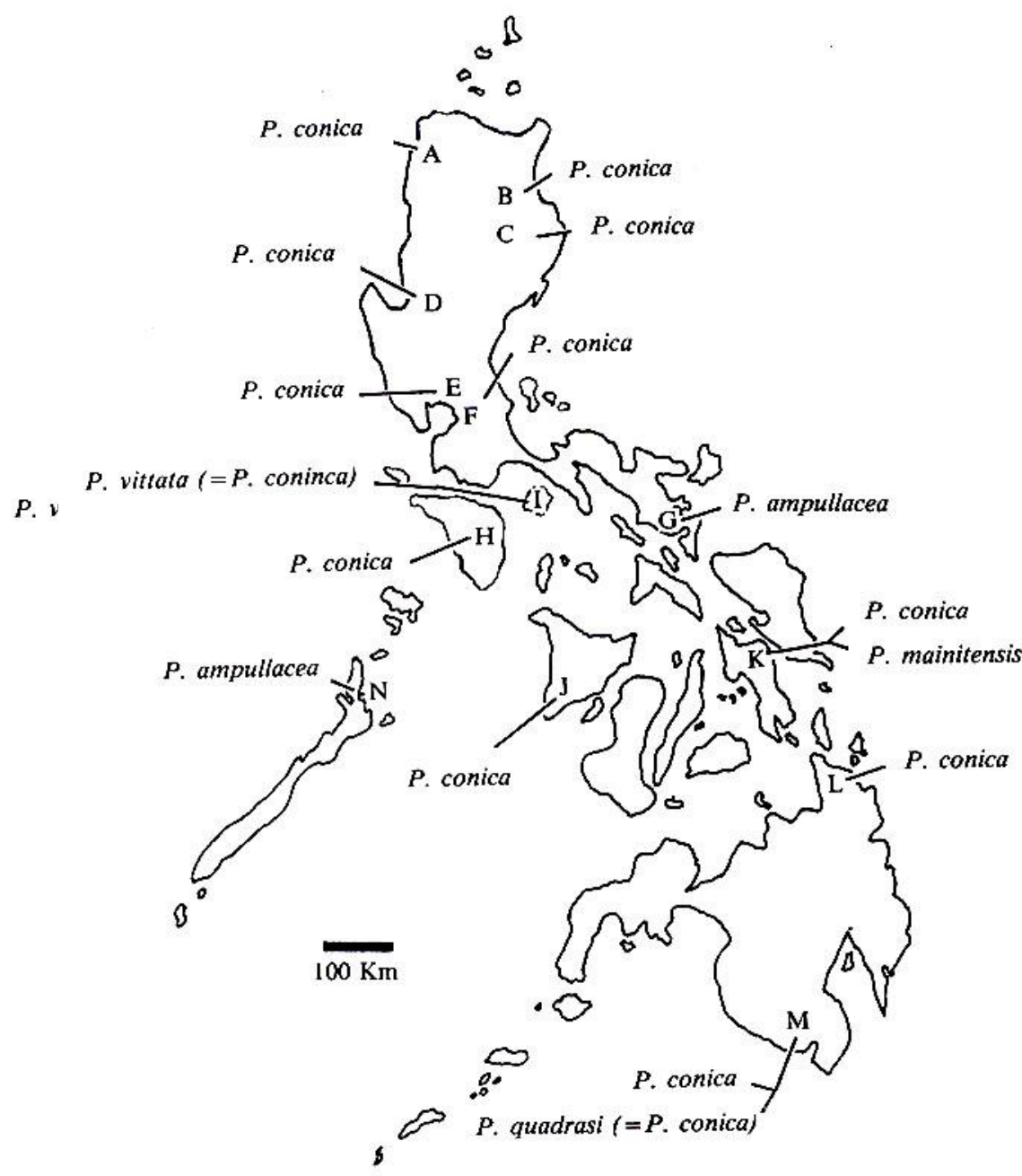

Figure 1. Species noted in the collection sites. A-Paoay, Ilocos Norte; B-Tuguegarao, Cagayan; C-San Isidro, Isabela; D-Caraen, Pangasinan; E-U.P. Lagoon, Quezon City; F-Tanay \& Montalban, Rizal; G-Magallanes, Sorsogon; H-Pinamalayan, Oriental Mindoro; I-Boac \& Sta. Cruz, Marinduque; J-Alimodian, Iloilo; K-Palo, Leyte; L-Mainit, Surigao del Norte; M-Lake Sebu, Marbel, \& Koronadal, South Cotabato; N-Lake Manguiao, Palawan. 
Notes on the family Ampullariidae in the Philippines - R.C. Pagulayan \& E.A. Remigio

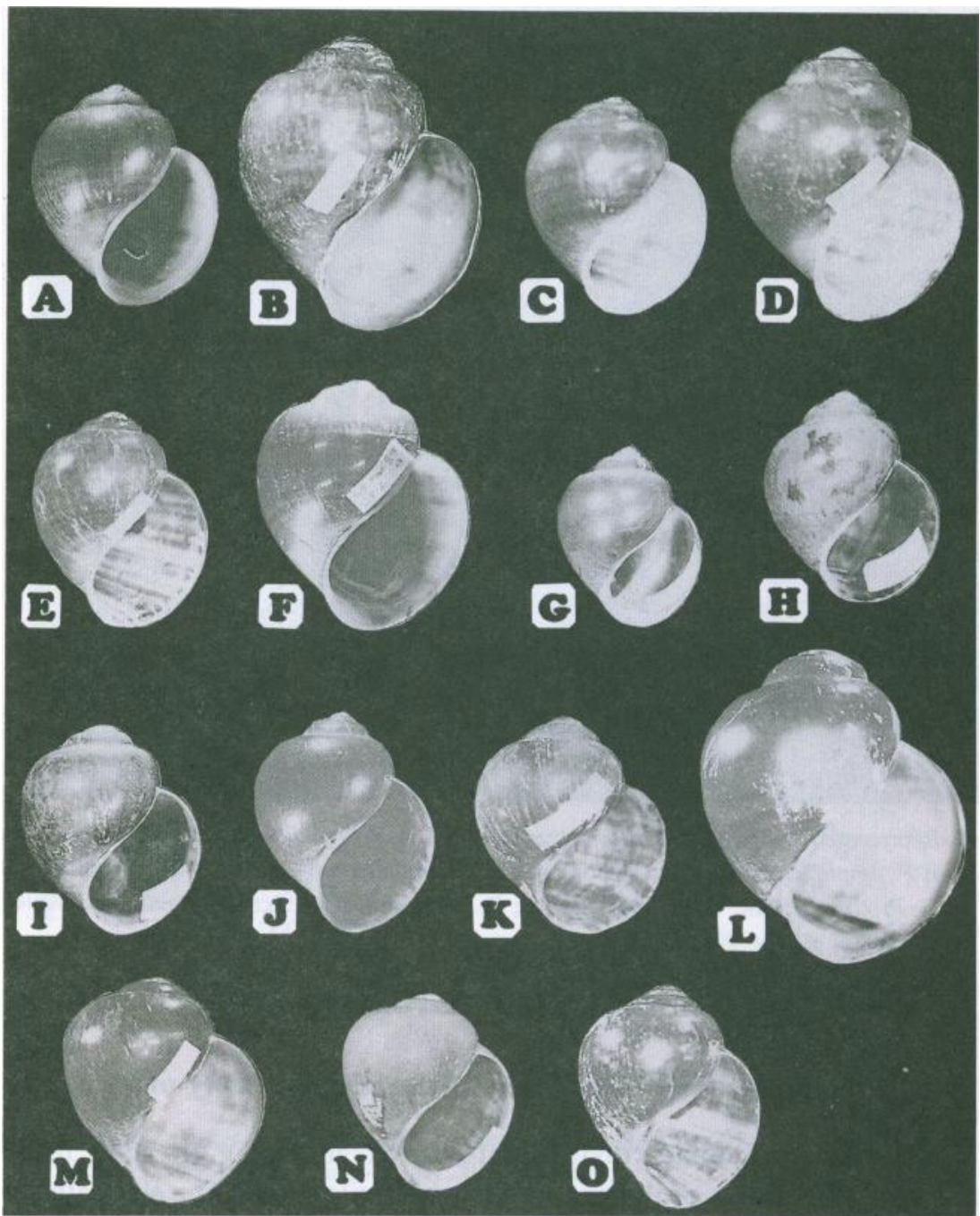

Figure 2. Representative shells of the snails identified as Pita conica from the following sites: A-Tuguegarao, Cagayan; B-Paoay Lake, Ilocos Norte; C-San Isidro, Isabela; D-Carmen, Pangasinan; E-U.P. Lagoon, Quezon City; F-Tanay, Rizal; G-Pinamalayan, Oriental Mindoro; H-Gacao, Palo, Leyte, 1-Hubang, Palo, Leyte; J-Alimodian, Iloilo; K-Lake Mainit, Surigao del Norte; L-Lake Sebu, So.Cotabato; M-Lamluad Valley, So. Cotabato; N-Marbel, So. Cotabato; O-Koronadal, So. Cotabato. Bar $=5 \mathrm{~mm}$. 


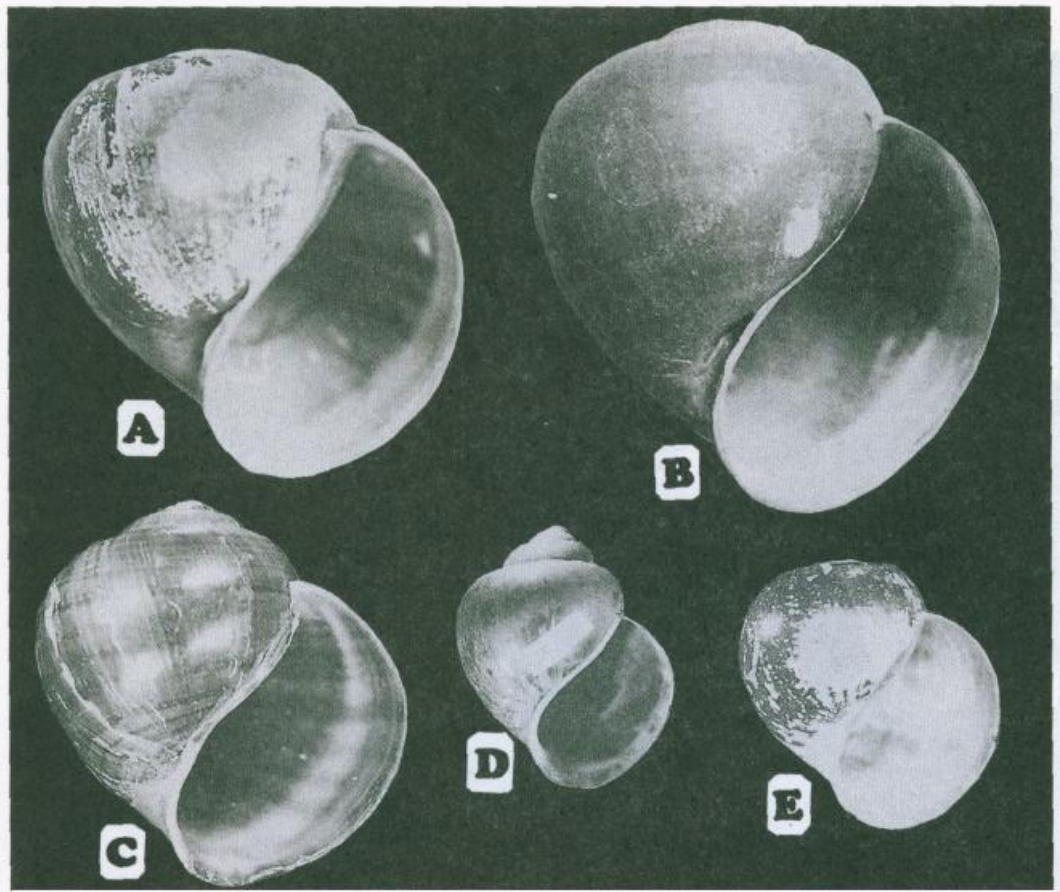

Figure 3. Representative shells of the other species collected. A.-P. ampullacea: Lake Manguiao, Palawan; 3-P. ampullacea: Magallanes, Sorsogon; C-P. mainitensis: Gacao, Palo, Leyte; D-P. vittata ( $=P$. conica): Sta. Cruz, Marinduque; E-P. quadrasi ( = P. conica): Lamluad Valley, So. Cotabato. Bar $=5 \mathrm{~mm}$.

\section{ANATOMICAL STUDIES}

\section{External Morphology and Description of the Mantle Cavity of P. conica}

The body of the animal is divisible into three regions (Fig.4) - head, foot, and visceral mass. The head is prolonged into a contractile snout. The elongated snout terminates anteriorly on its two sides into a pair of short labial pulps (LP) or tentacles. Posteriorly the head bears a pair of long contractile tentacles (TE). When fully extended the tentacles measure about $50 \mathrm{~mm}$ in length, thicker at its base but gradually tapering to a filamentous structure at the tip. When contracted, as when the animal is disturbed or as in the case of preserved specimens, the tentacles are reduced to about one-fourth of their length. The eyes (E) are situated on small stalks situated on the outer sides of the bases of the tentacles. Projecting anteriorly on the two sides of the head are two lobes. The left lobe forms the inhalant siphon (IS) and the right lobe forms the exhalant siphon (ES). 

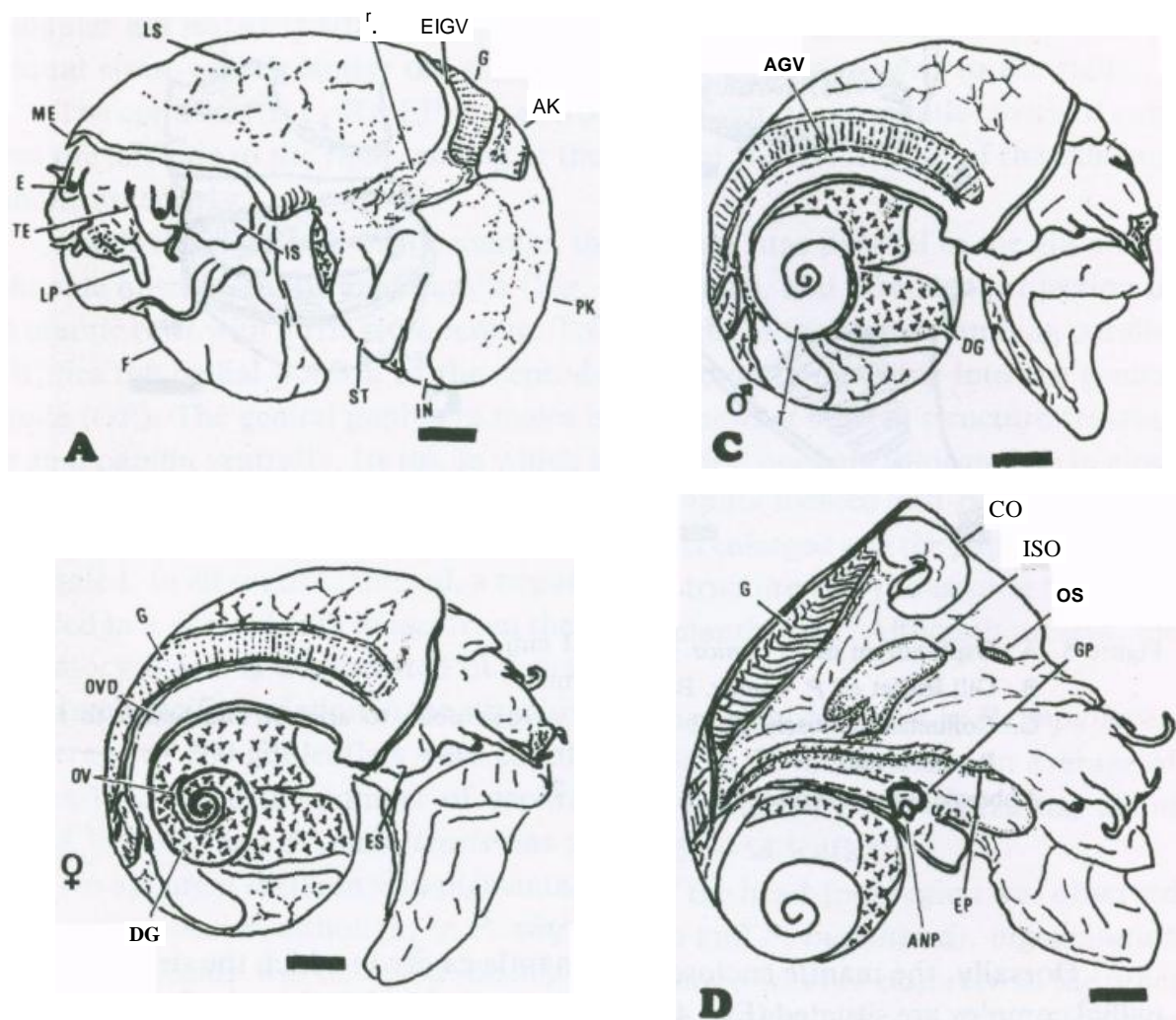

Figure 4. External features of the body of $P$. conica. A. left view; B. right view female; C. right view male; D. view of the mantle cavity. Bar $=3 \mathrm{~mm}$.

Abbreviations in figures see Appendix 2.

The foot $(\mathrm{F})$ is triangular in outline with the apex directed backwards. The sides are more or less arched in broadly rounded angles. The operculum is attached to the dorsal surface of the posterior half of the foot (Fig. 5C:OPL).

The columellar muscle (Fig. 5C) is seen as a broad band arising from its attachment to the columella and running longitudinally through the upper part of the foot to the operculiferous lobe (OPL) on the postero-dorsal surface. 

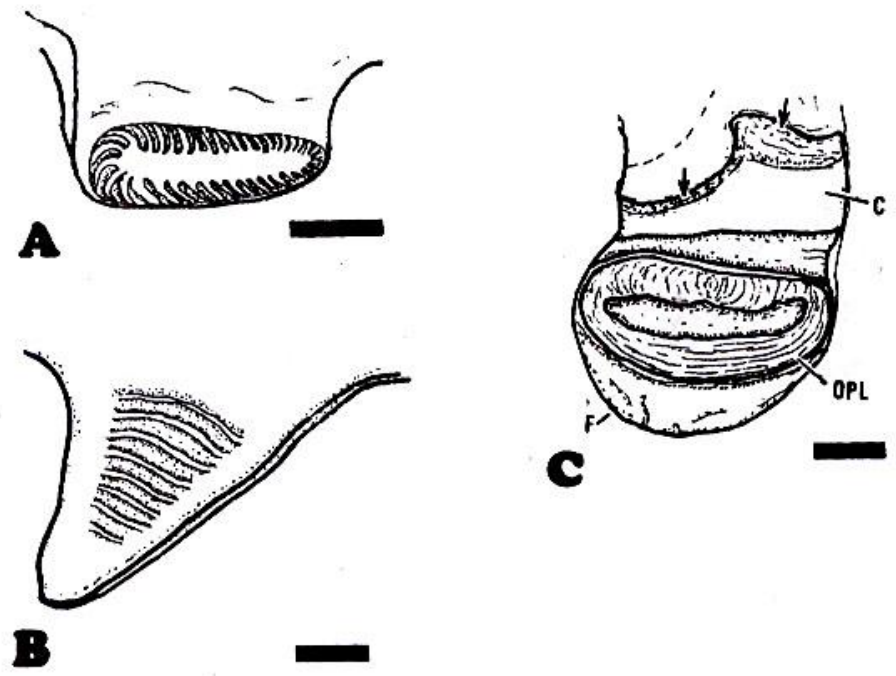

Figure 5. A. Osphradium of $P$. conica. Bar $=1 \mathrm{~mm}$.

B. Gill leaflet of $P$. conica. Bar $=1 \mathrm{~mm}$.

C. Collumellar muscle of $P$. conica. Arrows point to area of attachment to the shell. Bar $=6 \mathrm{~mm}$.

Abbreviations in figures see Appendix 2.

Dorsally, the mantle encloses the mantle cavity in which the structures of the pallial complex are situated (Fig. 4D). The mantle is thick along its free edges (ME). As seen dorsally, pigmented streaks run longitudinally from this free edge eventually coalescing to form a more or less united pigmented patch covering the mantle roof.

The pedunculate osphradium (Fig. 4D: OS \& 5A) hangs from the roof of the left side of the mantle close to the edge. It is elongate-oval in shape, somewhat pointed along its left margin and rounded on the right inner end. It is bipectinate and consists of an average of 35 fleshy leaflets arranged along its broad axis. The osphradium hangs transversely to the course of the respiratory water current as it flows into the mantle cavity.

Posterior to the osphradium and occupying the greater part of the mantle cavity is the pulmonary or lung sac (Fig. 4D: LS), arising from the ventral mantle wall as a more or less circular unpigmented folding with a ventral opening into the mantle cavity (LSO). The tissue of the pulmonary sac is moderately thickened and is richly supplied with blood sinuses. 
The gill or ctenidium (Fig. 4D: G \& 5B) is composed of approximately 170 triangular leaflets running alongside and to the right of the pulmonary sac. Each triangular gill leaflet is attached along the ctenidial axis and has two free sides of unequal sizes, consequently, the slightly rounded apex is skewed to the right.

The epitaenia (Fig. 4D: EP) arises from the floor of the mantle cavity. It runs from the left side to the right, ending at the base of the left margin of the exhalant siphon, anteriorly.

Inside the right wall of the mantle, the rectum runs parallel to the gill on the right side opening to the anal papilla (Fig. 4D: ANP), and extended projection of the mantle roof with a fringed opening. To the right of the rectum running parallel to it, lies the pallial portion of the reproductive duct terminating into the genital papilla (GP). The genital papilla in males is a somewhat conical structure crossing the anal papilla ventrally. Its tip, in which the genital opening is located, is in close contact, but not attached, to the base of the copulatory organ. In females, the pallial oviduct opens into a broad and short genital papilla located just beside the anal papilla. In egg-laying females, the genital opening is enlarged and the papilla is almost obliterated. In all snails examined, a copulatory structure $(\mathrm{CO})$ consisting of a penis enclosed in a penis sheath hangs from the right mantle roof. Although present, the copulatory organ is degenerated in females.

Interspecific variation in the structures of the pallial complex: In $P$. ampullacea, an average of 260 gill leaflets were counted, and in P. mainitensis, an average of 245 leaflets. As to the number of osphradium leaflets, $P$. ampullacea has about $58-68$ leaflets, and $P$. mainitensis has about 52 - 54 leaflets.

No apparent difference in pigmentation of the head-foot region was observed between the species, although, in $P$. ampullacea and $P$. mainitensis, pigmentation of the penis sheath was observed. Such pigmentation was not observed in the other species. The pallial complex of $P$. vittata and $P$. quadrase do not differ from that of P. conica.

\section{The Alimentary Tract of $P$. conica}

The buccal mass which forms the first part of the alimentary tract (Fig. 6A) is found inside the head sinus. The buccal cavity (Fig. 8D: BMC) is subdivided into different regions. The anterior region is rather small, bounded anteriorly by the mouth opening (MO) and posteriorly by the jaws (J). The skin forming its walls are thickened, partly pigmented, and with longitudinal folds. From the opening of the jaws, the cavity continues as a very short tube, then flattens with its margins arched ventrad and posteriad following the countour of the subradular organ (SO) and the more anterior portions of the radula. The cavity then widens a little on the level of the junction of the opening of the esophageal pouches. This region is 